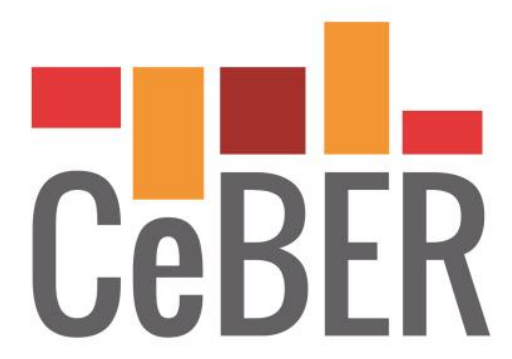

CENTRE FOR BUSINESS AND ECONOMICS RESEARCH UNIVERSITY OF COIMBRA

\title{
Dutch Disease in Central and Eastern European Countries
}

\author{
JOÃO SOUSA ANDRADE
}

CeBER and Faculty of Economics of the University of Coimbra

\section{ANTÓNIO PORTUGAL DUARTE}

CeBER and Faculty of Economics of the University of Coimbra

\section{CeBER Working Papers}

No. 3 


\title{
Dutch Disease in Central and Eastern European Countries
}

\author{
João Sousa Andrade \\ (jasa@fe.uc.pt) \\ António Portugal Duarte \\ (portugal@fe.uc.pt)
}

\section{GEMF, CeBER and Faculty of Economics, University of Coimbra}

\author{
Av. Dias da Silva, 165 \\ 3004-512 Coimbra, Portugal \\ Tel. +351239790500 \\ Fax +351239403511
}

\begin{abstract}
Bulgaria, Croatia, Estonia, Latvia, Lithuania, Hungary, Poland, Czech Republic, Romania, Slovenia, and Slovakia have all benefited from an increase of European Union capital transfers of funds since the demand for European integration. At the same time, foreign direct investments have risen, mainly due to the liberalisation of capital movements. The effects of those funds and the reduction of financial costs can be considered as analogous to the phenomenon known as Dutch Disease. That is to say, the inflow of financial transfers is also considered a curse. In order to eliminate this curse we must take into account the two effects associated with Dutch Disease: the 'spending effect' and the 'resource movement effect'. Public policies have not been appropriate and have not prevented the real exchange rate appreciation, thereby contributing to a poor performance in terms of competitiveness and economic growth. After a descriptive analysis of some variables, we estimate a set of equations that take account of the direct and indirect effects of European Union funds and financial costs on the economy where the effects on the real exchange rate play the major role.
\end{abstract}

JEL Classification: C01, E23, F43, H63, J31.

Key Words: GMM, foreign transfers, financial costs, Dutch Disease, Dynamic Models, and public policies. 


\section{Introduction}

During the last decades, namely in the 1970s, many natural resource-rich countries were faced with negative shocks as a result of the sharp escalation in energy prices. Large increases in oil prices have been considered responsible for economic recessions, high inflation, trade deficits, and high uncertainty, which all contribute to a decline in manufacturing growth and a loss of competitiveness following a strong real exchange rate appreciation. This leads directly to a deindustrialisation process (Caimcross, 1979; Égert and Leonard, 2008; Égert, 2012), manifested as a failure in output and employment in the manufacturing sector. Under these circumstances, most of the countries that experience a boom in natural resources tend to grow more slowly than countries without natural resources. Consequently, resource abundance seems to be a curse rather than a blessing (Sachs and Warner, 1997; Gylfason, 2001a; Auty, 2004; Hasanov, 2013; Smith, 2015).

There is a wide economic literature dedicated to the analysis of the impact of these shocks and the consequences of the adjustment policies followed by numerous countries to correct this phenomenon. It includes several representative studies devoted to the well-known 'Dutch Disease' (DD) problem faced by resource-exporting countries (see, e.g., Corden and Neary, 1982; Buiter and Purvis, 1983; Corden, 1984; Edwards, 1985; Rosenberg and Saavalainen, 1998; or more recently, Bénassy-Quéré et al. 2007; Chen and Chen, 2007; Lizardo and Mollick, 2010; Tiwari et al. 2013).

The simple and original definition of the DD phenomenon involves the following process: oil-exporting economies have periodically experienced significant increases in their national wealth due to higher oil or gas prices, natural resource discoveries, and/or technological progress in the energy sector. The booming demand caused by greater wealth, following the wages and expenditure increases, leads to a shift in an economy's productive factors from the tradable goods sector to both the non-tradable goods, and the natural resource sector. Such structural changes in favour of the natural resource sector, and the consequent decline of the tradable goods sector, was entitled the 'Dutch Disease' problem, denoting the apparently adverse and negative effects on Dutch manufacturing of that country's natural gas discoveries in the beginning of the 1960s. The economy's dependence on revenues from the oil and other natural resource-based sectors raises the possibility that the economy will be vulnerable to external commodity price fluctuations and, possibly, Dutch Disease effects. On its earlier presentation in Australia, this phenomenon wasreferred to as the Gregory effect (Gregory, 1976; Kutan and Wyzan, 2005; Clements et al., 2008). 
However, even if the oil prices are regarded as an important key determinant in explaining the behaviour of the real effective exchange rate, the literature frequently concentrates on industrialised and developing countries, leaving small open economies and transition countries outside the analysis. Indeed, only a few studies have been undertaken on the particular case of Central and Eastern European countries or for the rest of the former Soviet bloc.

The main aim of this chapter is to analyse whether recent economic developments in Central and Eastern European countries have been subjected to a typical process of DD. More specifically, we investigate the impact of foreign aid $^{1}$ on the economies of these countries through their effect on the real exchange rate $(\mathrm{RER})^{2}$. We assume that foreign aid has effects very similar to a boom in natural resources. It can ultimately be regarded as analogous to the initial effects of the DD phenomenon, although the existence of booms in capital inflows can also be originated through other sources such as workers' remittances, foreign direct investment, and even tourism (Andrade and Duarte, 2013; Silva, Andrade and Duarte, 2016). We apply robust ADF to determine whether the variables have a unit root or can be taken as stationary, and subsequently we applied ADL models (autoregressive distributed lag) models following the methodology of Arellano and Bond (1991) and Blundell and Bond (1998) to establish the impact of capital inflows on output growth via the determination of the real exchange rate, in the group of Central and Eastern European countries under scrutiny.

The choice of the countries studied may initially appear surprising, but in fact there is good reason. As in other industrialised and resource-rich developing countries, which experienced a period of undervaluation of the RER before the boom in natural resources, the RER in Central and Eastern European transition countries was also substantially undervalued at the beginning of the transition process. The recent history of the European integration is characterised by the accession of eight countries from Central and Eastern Europe to the European Union (EU) in May 2004, followed by a second-wave accession when another two countries joined the EU on the $1^{\text {st }}$ January 2007, which completed the transition process. Policymakers should thus focus their attention on the medium- and long-term implications of the RER appreciation that arises from the re-allocation of resources and expenditure effects associated with the natural resources sector or foreign aid developments. It is our conviction that these circumstances justify an analysis such as the one we develop in this chapter.

\footnotetext{
${ }^{1}$ Which, among others, can take the form of structural and cohesion funds.

${ }^{2}$ For a better understanding and analysis of the DD phenomenon, we will also refer briefly to the case of some post-Soviet transition countries.
} 
Besides this, the DD problem in Central and Eastern European countries has only been analysed in previous literature in its narrow sense relating to foreign exchange inflow shocks that result from the export of abundant natural resources, thereby ignoring almost completely, the impact of foreign aid inflows in the form of structural and cohesion funds. However, we cannot forget that in March 2010, the European Commission launched the 2020 Strategy for a smart, sustainable growth that would favour inclusion, and that would ensure the continuation of the Lisbon Strategy implemented since 2000. Under these conditions, our study, which takes into account the effects of foreign aid, assumes great importance and actuality given that these types of funds represent one of the most used instruments of the European Regional Policy to promote regional convergence among the Member States of the EU. So, if these capital inflows result in negative effects because of the presence of DD problems in the economies of these countries, the previous strategy and European integration itself to the East could also be jeopardised.

In this chapter, we identify the fundamental variables which allow the detection of the symptoms of DD in Central and Eastern European countries. Our focus is on two effects, reallocation and spending, for which we propose appropriate econometric modelling. The results confirm the presence of disease symptoms in this group of countries, and demonstrate that the effects of DD are both short and long-term. Moreover, we conclude our study recognising that the economic policy measures resulting from the transition process to the European Union have facilitated the development and deepening of DD.

After this introduction, the chapter is structured in five sections. Section 2 presents the concept of DD and the original Gregory effect. The idea of the natural resources curse is presented here, as well as some other forms of disease. Section 3 provides a brief theoretical and empirical review of the literature on the DD phenomenon in the context of Central and Eastern European countries. Section 4 seeks to detect the presence of disease symptoms in a group of Central and Eastern European countries with the help of econometric models that are able to give an answer with a reasonable level of certainty. Finally, section 5 concludes the chapter and presents some economic policy measures and recommendations that have been effective in comparison with those that were actually implemented in Central and Eastern European countries and also in the EU. 


\section{Dutch Disease and the Gregory Effect}

The term Dutch Disease refers initially to the economic consequences of the large natural gas discovery in the Netherlands during the 1960s, when the increase in wages generated by a boom in natural resources (the export sector), led to the strengthening of their currency, the Dutch guilder. Therefore, the competitiveness of non-natural gas exports on international markets decreased, and thus reduced the volume of exports of these goods, while the imports increased because foreign goods became relatively cheaper following the strong appreciation of the guilder. Employment in those non-natural gas sectors (manufacturing) was also consequently affected, since international markets were harder to service and competition from foreign goods on the domestic market increased. Besides this, the boom in natural gas production and exports in the Netherlands coincided with continuing trade liberalisation in the world and in particular at the time, in the European Economic Community (EEC), also exposing the non-natural gas sectors to more competition ${ }^{3}$. This economic paradox (Bayramov and Conway, 2010; Broz and Dubravčić, 2011) has since been recognised as the situation in which a booming sector adversely affects the performance of other sectors of a country, and in particular the non-booming tradable sectors. Thus, it is not surprising that despite the wealth windfall that the new discovery brought, the Netherlands experienced an important decline in economic growth.

In parallel with the DD problem, we can subsequently talk about the existence of a situation called the 'curse of natural resources', that we are able to translate in a simplified form as the DD curse in economies that are rich in natural resources. Although embracing similar subjects, the two concepts differ in the way they are related to the existing economic literature and, therefore, with the methods they use. The 'curse' literature has been mainly connected to development economics dealing with the effects of natural resources on economic growth rates of the countries. It is generally accepted that the curse of natural resources' is empirically confirmed since most natural resource-rich countries tend to grow more slowly than countries without natural resources. On the other hand, the 'disease' literature leans more towards international economics, preferring to explain the eventual negative effects of foreign exchange capital inflows (Sachs and Warner, 2001; Papyrakis and Gerlagh, 2004; Larsen, 2006; Iimi, 2007; Broz and Dubravčić, 2011). For an alternative point

\footnotetext{
${ }^{3}$ The increase in government income eventually also led to higher wages in the government sector and to larger social expenditures (CIEP, 2013). The major part of these expenditures is currently oriented to the non-tradable sector of the economy in the form of infrastructure and social projects (e.g., education investments), which are useful for socio-economic development.
} 
of view, see for example, (Davis, 1995) who finds that the 'curse of natural resources' is an exception rather than the rule. (Stijns, 2005; and Brunnschweiler and Bulte, 2008) also raise concerns over the validity of the 'curse of natural resources' hypothesis.

In this context and before proceeding, we must firstly consider the concept of DD and then discuss a little more the subject of the 'curse of natural resources', as well as other forms of 'illness' with which the DD can be associated.

\subsection{Dutch Disease}

The term 'Dutch disease' was first used in 1977 in an article in The Economist (The Economist, 1977) to describe the unfavourable effects on the manufacturing sector in the Netherlands following the discovery of natural gas during the 1960s. Because of these gas discoveries, the Dutch economy experienced an increase in its wealth, but this positive development in the natural gas and oil sector had negative consequences for Dutch non-oil exports by making the Dutch guilder stronger. The real exchange rate appreciation that followed seriously affected the manufacturing sectors, which gradually became less competitive. This particular economic impact has come to be known as Dutch Disease.

The study of the empirical results of the effect of a boom in a particular sector was, nevertheless, initiated in Australia (Clements et al., 2008), having been known by the Gregory effect (Gregory, 1976). While the DD phenomenon is better known as a process of interactions caused by structural demand changes in favour of the natural resource sector, it is also considered as one of the exceptions to the purchasing power parity in explaining the long-run behaviour of exchange rates ${ }^{4}$.

Subsequent to Gregory's denomination of the effect as DD, some theoretical contributions were made by other researchers who formalised the explanation of the mechanism of the DD in terms of economic theory (see, e.g., Corden and Neary, 1982; Bruno and Sachs, 1982; Buiter and Purvis, 1983; Corden, 1984; Edwards, 1985). The core model of DD presented is based on (Snape, 1977), which in turn is an extension of (Gregory, 1976)'s study. The initial goal when building the model was to provide an explanation of the phenomenon of deindustrialisation (Caimcross, 1979; Égert and Leonard, 2008), where the key to the dynamics was in the behaviour of the RER measured in terms of the prices of tradable goods over those of non-tradable goods (Neary, 1985). In fact, as a consequence of a

\footnotetext{
${ }^{4}$ The other being the productivity-bias hypothesis (Andrade and Duarte, 2013).
} 
shock caused by an increase of natural resources exports, which leads to a strong RER appreciation, the manufacturing sector loses competitiveness, manifested as a decline in output and employment, and this contributes directly to deindustrialisation. Under these circumstances, the main objective was to explain the co-existence of a growing sector of activity with other sectors that regressed. The first sector was identified as the mining industry: mining in Australia, natural gas in the Netherlands, and oil in the United Kingdom ${ }^{5}$, Norway and other producing countries. The development of technologically-advanced industries, as has happened in Ireland, Switzerland and Japan, can also be explained by this theory, which after all, is based on the principle of a markedly asymmetrical growth (Andrade and Duarte, 2013). Similarly, high income inflows of foreign capital to a given country, such as, for example, the current transfers of structural and cohesion funds from the the EU to Central and Eastern European economies, could also be the cause of this phenomenon.

Following the explanation of (Corden, 1984) that considers the production of three types of goods and not just 'industrial output' and 'services' as in the previous paper (Corden and Neary, 1982), the model assumes that the economy is divided into three sectors, classified as follows: B the growth sector (Booming sector), which experiences high export incomes, e.g., the oil sector, L the stagnated sector (Lagging sector), which consists of the non-booming tradable sector, such as agriculture and manufacturing, and $\mathrm{N}$ the sector producing non-tradable goods (Non-tradable sector). The first two sectors produce tradable goods at given world prices, while the third sector produces only non-tradable goods, which do not depend on world prices.

Under these conditions, a positive shock (resource boom) registered in the goods sector (B) will lead to a 'spending effect', in which incomes generated there, as well as the anticipation of future incomes (Neary, 1985), will lead to rising prices of non-tradable goods over tradable goods. Specifically, the 'spending effect' establishes that the boom in the natural resource sector, which may be caused by a rise in the world price of the resource, leads to increased income in a country and, consequently, to increased demand for tradable and non-tradable goods. However, since the prices of tradable goods are fixed internationally, this effect leads to rising prices of non-tradable goods relative to tradable ones, i.e., to a RER appreciation $^{6}$. This, in turn, causes productive resources to deviate from the B and L sectors,

\footnotetext{
5 The increase in unemployment in the United Kingdom, in the first half of the 1980s, was the result of the restrictive monetary policy of the governments of Mrs Thatcher, when in fact it should be understood as a result of the phenomenon of DD, and North Sea oil (Chrystal, 1984).

${ }^{6}$ With the real exchange rate (RER) defined as the ratio of prices of non-tradable goods to the prices of tradable goods denoted in the same currency.
} 
and move towards the $\mathrm{N}$ sector. In view of the boom in the natural resource sector, the marginal productivity of labour increases in the B sector, assuming the relative wage remains unchanged. This situation causes an increased demand for labour in the B sector, which will divert workers from both the manufacturing $\mathrm{L}$ and non-tradable $\mathrm{N}$ sectors. This is known in the literature (Corden, 1984) by the 'resource movement effect' or 're-allocation factors effect'. The displacement of workers from $\mathrm{L}$ to $\mathrm{B}$ reduces the production of sector $\mathrm{L}$, as a direct effect of deindustrialisation. At the same time, there will be movement of workers from $\mathrm{N}$ to $\mathrm{B}$, and the excess demand for non-tradable goods $\mathrm{N}$, associated with the previous effect, will increase the relative price of $\mathrm{N}$. This latter variation will lead to the displacement of workers from $\mathrm{L}$ to $\mathrm{N}$ because of the increase in the relative profitability of the non-tradable sector; and the movement will strengthen the deindustrialisation phenomenon associated with the first effect, being caused by the indirect effect. Indeed, the indirect deindustrialisation happens if the price of non-tradable relative to tradable goods rises, thereby drawing labour from the manufacturing sector to the non-tradable sector (Égert, 2012). The different effects are dependent in their magnitude on the different capital intensities. Furthermore, the presence of rents associated with the production of non-tradable goods may cause a reduction in their productivity (Torvik, 2002).

The decline of the non-booming tradable sector, initially identified as a phenomenon of deindustrialisation due to a reduction in the application of productive factors there, is one of the components of the adjustment to a new equilibrium situation (Neary, 1985). Almost simultaneously with the publication of the theoretical model of DD, (Bruno, 1982) presented a numerical simulation model where the author showed the effects of a boom initiated by the prices of 'energy' goods in an economy producing these.

However, it should be noted that in models such as those proposed by (Bruno, 1982; Wijnbergen, 1981; and Buiter and Purvis, 1983), only the 'spending effect' is considered. The 'resource movement effect' is completely disregarded. In respect of this latter effect, (Krugman, 1987) remarks that it gives birth to a major problem, that being that the nonbooming tradable sector cannot recover its relative loss of influence after the depletion of natural resources, which led to the boom. Nevertheless, the author considers that in principle, specialisation is beneficial, so he underestimates the dynamic effects of the destruction that it implies. An interesting case to be considered is foreign direct investment in Ireland in the 1980s and 1990s, which caused a reduced increase in wages because there was a high supply of skilled labour, thereby eliminating the resources effect of DD (Barry and Bradley, 1997). 
At the same time, the source of DD was precisely what in other cases, was the negative consequence: the investment in tradable goods.

Indeed, the real exchange rate appreciation that arises in the sequence of the resource boom will affect also the production of tradable goods. The export firms and those firms that compete with imports will be similarly crushed by the RER appreciation (Ye, 2008), hence, with the resulting adverse effects on economic growth (Wijnbergen, 1984). In addition to the fact that technological progress is faster in unprotected tradable sectors (Balassa, 1964; Samuelson, 1964), we can also add the knowledge that the learning-by-doing process is more important in this sector, and hence, the development of a non-tradable sector will affect economic growth (Hahn and Mathews, 1965; Krugman, 1987). Despite this reality, we should also consider that the transmission effect caused by the RER appreciation can be changed in less developed economies, in both sectors, the tradable and non-tradable (Torvik, 2001). The application of the funds generated by the boom in infrastructure and education investments, especially in those economies, as well as the possibility of the production being located to the left of the production possibilities frontier, may also lead to the conclusion that the effects of DD are not fully verified (Nkusu, 2004; McKinley, 2005).

\subsection{The Curse of Natural Resources}

Perhaps the first known cases of the curse of natural resources arose from the Iberian expansion ${ }^{7}$. In the early eighteenth century, coinciding with the temptation of gold from Brazil, Portugal passed from what (Godinho, 1968) called the 'cycle of sugar, tobacco and salt' to the 'cycle of Brazilian gold, Porto and Madeira', thus causing the development of manufacturing to fall behind. In the Spanish case, (Drelichman, 2005) notes the strong and persistent increase in the relative price of non-tradable goods, coinciding with the discoveries of silver for three decades, and ending with the bankruptcy of the Spanish Crown, in the last quarter of the sixteenth century.

Some centuries later, the question of the poor economic performance of natural resource-rich countries remains an open question (see, e.g., Gelb and Associates, 1990; Sachs and Warner, 1995; Ross, 1999; Sachs and Warner, 2001; Broz and Dubravčić, 2011; Hasanov, 2013; Smith, 2015). The identification of these countries as necessarily having this curse whereby $\mathrm{DD}$ dominates the evolution of the economy is common. In this respect,

\footnotetext{
${ }^{7}$ In the next two sections we follow very closely, the exposition we made in another study that we developed (see Andrade and Duarte, 2013).
} 
(Gylfason, 2001a) argues "Manna from heaven can be a mixed blessing" (p. 7). In turn, (Auty and Evans, 1994), like other authors, believe that this situation should not be considered a curse, whereas Davis (1995) rejects DD as a characterisation of evolution, associating it with an adjustment problem, and therefore considering it as a 'morbid' term.

It is worth mentioning that some recent research has emphasised that natural resource abundance is not a 'curse' and even promotes economic growth within well-designed institutional frameworks (Hasanov, 2013). By analysing institutional and constitutional aspects of resource-rich countries, (Brunnschweiler and Bulte, 2008) conclude that resource abundance does not affect economic growth. On the contrary, resource dependence positively influences both growth and institutional quality. Their main finding is that the notion of 'resource curse' is actually a "red herring" (p. 250).

Given these different perspectives, a question arises. Which countries, rich in natural resources, have not experienced this 'curse'? Certainly, Netherlands (1990s), Botswana, Indonesia, Norway, and the United Kingdom (Hjort, 2006) have managed to escape it, but there are many other examples of economies with high revenues from natural resources that have reported disappointing results (Larsen, 1998), including political instability, such as Venezuela, Indonesia, Mexico, Nigeria, Angola and Bolivia (Garber, 2004). The exceptions are those with good results and growth in performance.

We can summarise a substantial part of the literature asserting that in natural resource-rich countries: i) additional "laxist" policies are more tolerated; ii) there is lower pressure for rapid industrial growth; iii) groups living from rents are more tolerated and governments are prone to be captured by those groups, jeopardising the quality of democratic institutions; iv) there is a greater probability of a slower economy and erratic economic growth; v) there is a higher tendency to neglect education; and vi) the population will become accustomed to depending on the State such that individual initiatives are neglected and there is a reduction in the propensity to save (see, e.g., Amuzegar, 1982; Auty, 1994; Usui, 1997; Auty and Gelb, 2000; Torvik, 2002; Kutan and Wyzan, 2005; Gylfason and Zoega, 2006; Oomes and Kalcheva, 2007; Tiwari et al., 2013).

An economy rich in natural resources will benefit from capital inflows in international foreign currencies, which, in turn, lead to the appreciation of its currency in nominal terms. At the same time, the increased domestic purchasing power following the greatest national wealth will increase inflation due to the generally inelastic supply of goods and services. In short, the result will be an appreciation of the RER. In parallel with this RER appreciation and the growth in non-tradable production fuelled by incomes from the exploitation of those 
resources, we have an unsustainable Gross Domestic Product (GDP) growth, and an increase in the supply of foreign loans (Usui, 1997). Consequently, the external debt will increase in general in an unsustainable way.

In our opinion, the 'resources curse' version of DD should be thus understood as a global process, including what Ross (1999) called categories of this explanation: cognitive, representing the short-run deviation associated with the fast increase in domestic incomes; societal, in which the boom leads to the empowerment of sectors and groups of interest; and policy, in which the boom weakens public democratic institutions. It is these phenomena that fuel the curse by the inexorable development of DD. The DD phenomenon should be seen as involving a strictly economic component, but also other components, which determine the environment in which policies may be developed. Dutch Disease, like most diseases, can be counteracted, but for that to happen, the political and sociological environment must be favourable to the appropriate policies.

The results of (Gylfason, 2001b) are surprising. On average, of the 65 countries classified as rich in natural resources during the period 1970 to 1998 , only four countries (Botswana, Indonesia, Malaysia, and Thailand) reached a proportion of at least $25 \%$ of investment on GDP and a growth of GDP per capita exceeding 4\% for the same period. Under these circumstances and to conclude, we can say "Rich parents sometimes spoil their kids. Mother Nature is no exception." (Gylfason, 2001b, p. 850).

\subsection{Other Initial Forms of Dutch Disease}

The undesirable symptoms of Dutch Disease are mainly connected with natural resource discovery, which as we saw previously, results in a large inflow of foreign currency and consequently in a real exchange rate appreciation with negative effects in terms of competitiveness and economic growth. However, the existence of booms in capital inflows can also be originated through other sources, such as foreign aid, worker's remittances, foreign direct investment and even tourism, which can also start this economic disease.

Since our main goal is to analyse the effects of international financial aid on Central and Eastern European countries, although in this section we present some other alternative forms of the DD phenomenon besides natural resource discoveries, we will focus our attention mainly on the effects of foreign aid. Let us start, nonetheless, by analysing the mechanisms of disease transmission in the case of the flow associated with workers' remittances. 
The flow of workers' remittances, i.e., the repatriated earnings of migrant workers, are an important determinant of aggregate demand increase since they provide an additional source of income for recipient countries, twice as large as the level of official aid in developing economies (Adams and Page, 2005). In this context, remittances usually have a positive impact on inflation and as a result, exports are affected. This expense effect has been witnessed in various countries ${ }^{8}$ during periods of high inflation as being accompanied by a reallocation effect of resources toward the non-tradable sector (Lartey, 2008). We can also assume that the increase in disposable income of households will reduce the labour supply as well as increasing consumption, which in the case of inelastic supply of non-tradable goods, leads to a fall in exports (Acosta et al., 2009; Bayangos and Jansen, 2011; Rabbi et al., 2013; Nikas and Blouchoutzi, 2014). Thus, remittances may be increasingly used as income substitutes for domestic production, which supports the 'dependence effect', sustaining the overall supply retrogression (Silva et al., 2016). This is in fact, the DD argument applied to worker's remittances. The combined effect of the received income and the fall in labour supply will lead to a strong increase in wages and production costs, and to a decrease in the unemployment rate. Unlike other capital flows, such as foreign aid, the remittances are an almost permanent source of resources (Buch et al., 2002) and can reach higher values than the private capital inflows (Loser et al., 2006). Consequently, they can lead to significant RER appreciations. For example, (Amuedo-Dorantes and Pozo, 2004), using pooling annual data for thirteen Latin American countries, find that a doubling of workers' remittances would lead to a RER appreciation of about $22 \%$.

But if all these aspects are negative in terms of tradable goods production, we cannot forget that their application in investment can also benefit the production of these goods. In fact, in this respect it can be said that while the core model of DD makes unambiguously predictions regarding the negative effects of a resource boom on the manufacturing sector, the literature on the alternative sources of DD applied to workers' remittances has not clearly identified such effects. (Amuedo-Dorantes and Pozo, 2004; Bourdet and Falck, 2006; Acosta et al., 2009; Bayangos and Jansan, 2011; and Lartey et al., 2012), for example, all show for the case of various developing and transition countries, the positive effect of immigrants' remittances on the RER.

\footnotetext{
${ }^{8}$ The second wave of emigration that occurred in Portugal in the 1960s and 1970s - the first happened at the end of the nineteenth century - is a good example of this, where the remittances accounted for a growing flow, reaching on the eve of the Revolution of 1974, about 6\% of workers' wages in the Portuguese economy. For more details see, e.g., (Castro, 1970) and (Pereira, 2011).
} 
The symptoms of Dutch Disease derived from foreign direct investment (FDI) inflows were initially analysed by (Athukorala and Rajapatirana, 2003) in a comparative study for Latin America and Asia for the period between 1985 and 2000. The authors conclude that while the RER appreciation is a phenomenon associated with other non-FDI forms of capital inflows, the results suggest contradictory effects in both regions of countries. Indeed, FDI may be related with RER depreciation, since FDI shows a greater bias towards tradable goods when compared to other capital inflows. In contrast, (Lartey, 2007), using dynamic panel data for a set of Sub-Saharan countries, shows that FDI is positively correlated with RER appreciation and, consequently, with losses of competitiveness in exports. Similar conclusions are obtained by (Javaid, 2011) for a group of Southeastern Asian economies.

Under these circumstances, as suggested by the case of workers' remittances, the possibility that FDI constitutes an initial form of DD is not consensual. The sectorial orientation of such capital inflows is crucial for resource allocation, but also for the effects caused on the RER (Silva et al., 2016).

Beyond the phenomenon of remittances and FDI, tourism activity can also give rise to the phenomenon of DD. A boom in the tourism sector increases demand for non-tradable goods, leading to the re-allocation of resources in favour of the production of these goods, which is typical of DD. Based on a comparative analysis applied to tourism-oriented Spanish regions, the Balearics and the Canary Islands, which experienced a tourism boom in the early 1960s, (Capó et al., 2007), conclude that there were signs of DD, low levels of education, innovation and technological progress, resulting from tourism specialisation. Similar conclusions are found by (Blake and Gooroochurn, 2005) for the particular case of Mauritius. Hence, we may be facing a case that will culminate in deindustrialisation (Chao et al., 2006; Sheng, 2011). In contrast, (Kenell, 2008) investigated the case of Thailand's increasing tourism activity, concluding that the harmful DD effects of deindustrialisation and RER appreciation did not materialise. The main explanation for that result was that Thailand's economy was not tourism-dependent, the manufacturing sector being the major contributor to the GDP. More recently, (Sheng, 2011) refers to a vast number of studies that also demonstrate DD problems to be present in tourism destinations. The most common solution proposed to prevent the deindustrialisation which occurs in consequence of the DD, is a fiscal levy on tourism activity in parallel with the promotion of investment in tradable goods.

In the case of financial aid, which in practice provides an increase in foreign exchange reserves availability with little or no additional use of domestic factors of production, governments spend this once they have received it (Allen, 2005; Gupta et al., 2005). In this 
scenario, the prices of non-tradable goods rise, the tradable sector becomes less profitable, affecting growth, and the inflation rate increases, leading to the appreciation of the RER, which reduces the competitiveness of the economy, and negatively affects the export sector (Rajan and Subramanian, 2005). The weaker the development of the economy, the lower the elasticity of domestic supply and, therefore, the more important the RER appreciation (Wijnbergen, 1985). The increased production of non-tradable goods and the reduced production of tradable goods, which are no longer competitive, may therefore, be normal consequences of financial aid, which simply reflect DD problems. Other effects, of a foreign exchange nature, may reinforce this evolution. For example, the conversion of international foreign currency resulting from aid in national currency (Allen, 2005), and the reduction of the risk premium driven by aid (Kuralbayeva and Vines, 2007), can also lead to nominal appreciation of the exchange rate.

In the case of poor countries, the effect of foreign aid inflows on public infrastructure accompanied by a limitation in the RER appreciation can offset the expected negative effects of DD, as shown by (Adam and Bevan, 2003). The effect caused by the aid can be taken as analogous to the natural resources (Torvik, 2002), where the boom is not caused by the discovery of new resources, but by the rising price of existing and already explored resources (Algieri, 2004). In this latter case, the price increase may even be a parallel movement with the RER appreciation (Kutan and Wyzan, 2005) 9 .

The foreign aid will have a growth effect in the demand for non-tradable goods, especially in the construction sector (infrastructures), but also in health care services, education and other personal services. This demand will increase wages and profits in these sectors. The increase is however differentiated because the supply of skilled workers is limited and not all of those sectors are consumers of skilled workers in similar proportions. This situation causes the movement of resources, capital and labour, from the tradable goods sector to the latter, the non-tradable goods sector. Since the prices of tradable goods are given, the profit in this sector reduces and so the importance of non-tradable goods in relation to tradable goods increases. As we said before, this is what (Corden and Neary, 1982) designate as the 'resources movement effect'. Wages and higher profits will lead to higher prices in the non-tradable sector and to RER appreciation. Those authors described this latter effect as the 'expense effect'. (Rajan and Subramanian, 2011) question why it is so difficult

\footnotetext{
${ }^{9}$ The result of a negative effect of the terms of trade evolution on RER can be seen as the anticipation of the effect of the DD phenomenon and not as an unexpected effect as presented for the case of Chile, India, and Mali by (Elbadawi and Soto, 1997).
} 
to find robust confirmation of the positive effects of international financial aid in the standard of living of those who receive it, when this is after all its first goal. However, since 1970, it has been understood that aid can replace domestic savings and thus negatively affect economic growth (Griffin, 1970). Perhaps the economist's opinion is induced by moral reasons: we must not negatively evaluate acts of altruism of others.

Contrary to the belief of Burnside and Dollar (1977, 2000), Hansen and Tarp (2001) support (empirically) the proposal that monetary inflows corresponding to aid contribute to increasing growth in a non-conditional form in good policies. What should happen is for foreign aid to show decreasing returns but its empirical verification is dependent on the variables used (Hadjimichael et al., 1995; Durbarry et al., 1998; Lensink and White, 1999; Gomanee et al., 2003), and the effects are felt only from certain levels of aid (Burnside and Dollar, 1977, 2000; Gomanee et al., 2003).

The effect of international financial aid is dependent on the foreign exchange appreciation associated with it. The final effect on the product will be negative for more important appreciations and positive for weaker appreciations (Kang et al., 2012). When controlling investment and human capital, the effects of aid tend to disappear. The reason for this result may be the fact that foreign aid has effects on economic growth, but through investment and education. Also of note is that these studies involve poor countries with low and very low levels of human capital. The contribution of (Nkusu, 2004) summarises the studies with conflicting results on the effects of foreign aid. In this respect, the author draws attention to the adverse effects of aid and emigrants' remittances in poor countries through the RER appreciation, but insists that using public resources inefficiently is more onerous than the negative effects of RER appreciation. Also (Barder, 2006) insists on the proper use of aid funds, but suggests its evaluation should be on welfare rather than output, thus enhancing the effects on consumption (and investment). However, these can be only transitory if there are no positive effects on the product.

If there is a threshold effect for foreign aid to have positive effects, there also seems to be a threshold from which its effects are clearly negative. (Rajan and Subramanian, 2011) show that in countries that receive more aid funds, the effects of foreign exchange appreciation are more pernicious on exporting firms than on those that do not export, or export less. Thus, a negative association is found between massive aid and loss of competitiveness. The analysis in the European case must also take into account the European regions that contribute to this support, and in this case the study of (Checherita et al., 2009) shows, for the period of 1995-2005, that the effects of net transfers, although negative for all 
regions, turn out to be more onerous for the highest contributors. The authors admit, however, a slight positive effect of structural funds spending between 1994 and 1999 in terms of future economic growth through human capital formation. This last result can be classified as politically correct, since in the paper it can be rejected based on normal statistical tests of nullity.

International financial aid can thus be associated with a paradox ('transfer paradox') in which the recipient country of the aid may be in a worse situation after receiving such assistance than before (Brakman and van Marrewijk, 2005; Adams, 2006).

The effects of foreign aid inflows are usually studied through the 'expense effect' of DD. The attempt to reduce a demand considered too high by monetary policy leads to the appreciation of the RER. This is the main reason why the reduction of the negative effects of aid, acting on demand, must be managed through fiscal policy (Vos, 1998). The foreign aid can be associated with the maintenance of imprudent macroeconomic policies, being contemporary with reductions in economic activity as indicated by (Griffin, 1970) in four countries of the Communauté Financière Africaine (CFA). The dependence on the international financial aid may also lead to the absence of production initiatives and higher domestic wages, preventing economic growth, such as in Greenland (Paldam, 1997).

A case of the effects of DD being made worse was that of East Germany during its integration into the Federal Republic of Germany. In this case, as well as the effects of aid on the RER, the exchange conversion between the two currencies involved led to the appreciation of the East German currency by $450 \%$ (Sell et al., 1999).

Let us now examine in more detail the effects of these various forms of DD in Central and Eastern European countries.

\section{Dutch Disease in Central and Eastern European Countries: Literature Review}

In the past three decades a sizeable literature on the DD phenomenon has examined the commodity booms experienced by some economies. However, the literature has mostly concentrated on industrialised and developing countries, and on the abundance of natural resources, leaving small open economies and transition countries virtually outside the analysis, as well as the other forms of DD. Indeed, only a few empirical studies have been undertaken on the particular case of Central and Eastern European countries or for the rest of the former Soviet Union. Additionally, the majority of these studies considered the oil price as the only determinant of the movements of RER, ignoring almost completely, the effects of foreign aid (cohesion and structural funds) on the transition process of these countries and, 
specifically, on their efforts to integrate within the European Union (EU).

However, we cannot forget that in March 2010, the European Commission launched the 2020 Strategy to overcome the negative effects of financial and economic crisis from 2008 and prepare the EU economy for the next decade by promoting convergence and potential long-term economic growth in the member-countries of the EU. Bearing in mind that in Central and Eastern Europe there are eleven member-countries of the EU (Bulgaria, Croatia, Estonia, Latvia, Lithuania, Hungary, Poland, Czech Republic, Romania, Slovenia and Slovakia), six countries of the former Yugoslavia (Albania, Bosnia-Herzegovina, Macedonia, Montenegro, Serbia and Kosovo), and four former Soviet republics (Belarus, Moldova, Ukraine and Russia), the analysis of the phenomenon of DD within this group of countries becomes very important, not only to gain an understanding of the effectiveness of attracting and using EU funds, but also to obtain a better knowledge of the transition and enlargement process in the $\mathrm{UE}^{10}$.

Under these circumstances, it is our intention in this part of the chapter to proceed with the review of the economic literature devoted to the analysis of the DD phenomenon in this type of economy. We begin by analysing the phenomenon in some of the post-Soviet transition economies, such as, Azerbaijan, Kazakhstan, Turkmenistan and Uzbekistan, concentrating later on Central and Eastern European countries and, in particular, in the case of the group we study.

The studies that investigate the theoretical mechanisms of the DD and their empirical implications in the context of post-Soviet transition countries, allow us to conclude that there is no wide consensus that countries whose economic structures depend on natural resources abundance are necessarily penalised in the long-run in terms of competitiveness and economic growth.

For instance, (Hasanov, 2013) tests empirically, some of the main hypotheses of the DD phenomenon in the Azerbaijan economy, one of the most important natural resource-rich countries of the former Soviet bloc, observing that the Azerbaijan economy, as many other resource abundant (mainly oil) economies, has experienced substantial economic growth over the last several years. The oil extraction and oil exports have been growing substantially, thus turning into a leading sector of the economy. Huge oil revenues, driven by the high oil prices and an expansion of oil production, have been the major sources of the enormous increase in

\footnotetext{
${ }^{10}$ This is the reason why in the next section of this chapter we developed an empirical study where we investigate the impact of foreign aid on a group of Central and Eastern European countries through their effect on the RER.
} 
government expenditures in the forms of infrastructure and social projects, which are useful for the socio-economic development. However, the boom in the oil sector has also been accompanied by some negative trends in the economy. The objective of (Hasanov, 2013)'s was to diagnose the DD symptoms in the Azerbaijan economy, and then carefully test the theoretical hypotheses associated with this phenomenon.

By dividing the economy into the three sectors, namely the oil, non-oil tradable, and non-tradable sectors, the author concludes that during the period 2000-2007 there has not been 'absolute deindustrialisation', but rather 'relative deindustrialisation' of the non-oil tradable sector, and that the non-tradable sector has substantially expanded. The paper also shows that the government expenditures have created a 'spending effect', which is more crucial than the 'resource movement effect'. Furthermore, it was found that rapid increases in the wages and the non-tradable prices have led to RER appreciation in Azerbaijan. Finally, the study reveals that FDIs in the oil sector are harmful for non-oil exports and therefore, it deepens natural resource dependence of the economy. The author also suggests, as a policy implication of the study that a development of the non-oil tradable sector should be the major focus of policymakers in order to obtain a diversified economy and, consequently, long-term sustainable and balanced economic growth.

Although the Azerbaijan economy has not been investigated systematically in terms of the DD phenomenon, some years before, (Rosenberg and Saavalainen, 1998; Singh and Laurila, 1999; Kronenberg, 2004; Kutan and Wyzan, 2005; and Égert, 2009) found similar empirical evidence to that obtained by (Hasanov, 2013), even though, in addition to the Azerbaijan economy, their studies focused on a wider set of transition countries.

For the period between 1995 and 1998, (Rosenberg and Saavalainen, 1998) show that due to the nature of resource price, the Azerbaijan economy could be vulnerable to short-term recessions, since its RER has appreciated more than in other countries of the former Soviet Union, such as in Kazakhstan, Turkmenistan or Uzbekistan, which is a result of nominal exchange rate appreciation and monetary conditions. On the contrary, (Singh and Laurila, 1999) conclude that the DD syndrome, seen through an appreciation in RER, is not a problem at the time, but may become one in the medium or long-term. Additionally, the paper reports that government revenues were highly leveraged on oil exports and that the financial intermediation process was not operating efficiently. In this context, the authors suggested faster structural reforms in the public finance and banking sector. (Kronenberg, 2004) goes even further, concluding that a strong negative correlation exists between natural resource abundance and economic growth in some transition economies including Azerbaijan. Using 
an extended version of the Balassa-Samuelson model with the price of oil, (Kutan and Wyzan, 2005) also find evidence that changes in oil prices have significant effects on movements in the RER during the period 1996-2003, suggesting symptoms of important DD effects in Kazakhstan as a consequence of the RER appreciation. Following the same line of thought, the results of the study of (Égert, 2009) show that oil prices cause nominal and real appreciation in former Soviet Union countries and, to the extent that non-oil manufacturing cannot stand the pressure, this will lead to a deindustrialisation process.

Concentrating the analysis of the DD phenomenon exclusively in the case of the Russian economy or comparing it with the rest of post-Soviet transition countries, several other authors (e.g., Bayulgen, 2005; Smirnova and Kulkarni, 2006; Korhonen and Juurikkala, 2007; Sosunov and Zamulin, 2007; Égert, 2012), have also investigated the presence or lack of DD problems by observing the export trend, the political factors associated with attracting FDI, and the impact of other macroeconomic monetary variables on the behaviour of the exchange rates in the Russian economy. Again, the results point to the absence of consensus regarding the presence of long-term negative effects resulting from the transmission mechanisms associated with the phenomenon of DD.

Some recent investigations also analyse the economic impact of remittances in small transition economies, such as in the case of Albania, Armenia, Kyrgyzstan, Moldova and Tajikistan (Karapetyan and Harutyunyan, 2009; Nikas and Blouchoutzi, 2014). In general, these studies conclude that remittances lead to DD, as they contribute to the appreciation of the effective exchange rate with negative consequences in terms of competitiveness and economic growth. The origin of this exchange rate appreciation can differ from country to country, but the inflow of remittances, the main and clearer gain for the recipient countries, has been accused of causing such disease. These countries are also particularly exposed to external shocks, such as the recent economic and financial crisis, as domestic shocks are exacerbated by pressure in the labour market in destination countries, through lower demand for a migrant labour force, and lower levels of consumption and investment, stemming from reduced remittance inflows.

But if in the literature we can find studies that analyse the DD problems from the effects of emigrant's remittances in small transition economies, we can also identify some empirical studies investigating the impact of EU structural and cohesion funds in Central and Eastern European countries in the context of the DD phenomenon. In fact, EU funding is one of the most-used instruments of the European Regional policy to promote regional convergence among the new member-countries of the EU. However, there are theoretical and 
empirical differences in the literature regarding their capacity to promote economic growth. In this context, taking into consideration that in the process of EU development, Central and Eastern European countries had to cope with the institutional transition that was supposed to ensure the premise of an economic growth destined to stabilise the gap between these countries and Western countries, it is very interesting to analyse to what extent the funds available by the EU were a catalyst for long-run economic growth for the Central and Eastern European Member-countries.

(Dorin-Madalin, 2015) has recently conducted a study aiming to show the way in which seven Central and Eastern European countries (Bulgaria, Poland, Czech Republic, Hungary, Slovenia, Slovakia and Romania) managed to use the funds made available to them in the 2007-2013 budget through the three mechanisms of: European Development Fund, Cohesion Fund and the European Social Fund. The author concludes that these European funds have a positive impact on all the seven Central and Eastern European countries analysed, namely in the development of human capital, the development of infrastructures, and the improvement in the legislation gaps. These impacts arise purely through the public purchases made in these connections. However, together with these positive aspects of structural funding, (Dorin-Madalin, 2015) also found these countries to encounter certain problems while attracting this type of foreign aid. Specifically the lack of authorised personnel in the state structures caused a high absorption of funds compared to the given budget for different operational programmes (about 174 billion of euros, which represent $16 \%$ of their GDP). Additionally, there are contradictions between the internal and European legislation, resulting in corruption and the inability to exclude the presence of some signs of DD in these economies due to the international capital flows associated with these structural funds.

(Neculita et al., 2013; and Neculita and Neculita, 2014) also propose an integrated analysis of the impact of European financial aid in Central and Eastern European countries by analysing the relationship between the absorption of EU funds by these countries and their economic growth. The authors show that a better absorption of European funds can lead to growth and economic development and thus contribute to reduce regional economic disparities. In this context, everything seems to indicate that international capital flows through European funds are not a curse, and can even promote regional convergence and economic growth in Central and Eastern European countries.

That view is not, however, shared by (Broz and Dubravčić, 2011), who conduct a comparative analysis of the DD phenomenon in Slovenia and Croatia, taking into 
consideration the cumulative effects of foreign exchange inflows from foreign tourism, workers' remittances, and net capital inflows (the sum of direct and portfolio investment and changes in the foreign debt position). The authors test the proposition that the DD problems result from excessive total foreign exchange inflows from various sources, exports of natural resources not necessarily being one of them. The comparison of relevant developments in Croatia and Slovenia give effective support to the DD diagnosis, particularly in the case of Croatia. The exchange rates of the Croatian currency (kuna) held steady to the Euro, even appreciating slightly, while those of Slovenia (the Slovenian Tolar, before the country joined the Euro area) fell, following a trend that could be expected in unstable macroeconomic conditions during the transition process. The data on money supply and increasing foreign exchange reserves show that the influence of market forces (abundant supply of foreign exchange) in Croatia was strong and that the central bank actually intervened trying to limit the RER appreciation. The overspill of foreign exchange windfall to wages, which rose much quicker than in Slovenia, certainly contributed to the decline of the competitive position of producers of tradable goods in Croatia, leading to the deindustrialisation of the Croatian economy (Broz and Dubravčić, 2011: 62). Under these circumstances, this result may certainly be relevant for transition countries that want to join the Euro area although they are suffering from the disease caused by large capital inflows.

As observed by (Lupu and Asandului, 2015), Eastern European countries entered the transition process with relatively low levels of regional disparity as compared to countries having a market economy tradition. However, these disparities have rapidly grown and, in particular, between the regions that include the capital and other regions, hence the great importance of both the European financial funds transfers and FDI for the development of these countries as a whole, and of their most disadvantaged regions, in particular.

Another study concerning the subject of DD in Central and Eastern European countries was performed by (Tiwari et al., 2013), intending to assess the empirical influence of oil prices on the evolution of the exchange rate. More precisely, the authors investigate to what extent oil prices impact upon the real effective exchange rate in a small Eastern European transition country like Romania, characterised by a low level of retail fuel prices and by an important growth rate in these prices in the last years, as compared to the other EU countries. In fact, according to the European Commission Oil Bulletin, in November 2012, the lowest level of gasoline and diesel prices among the EU countries was recorded in Romania. As compared to January 2009, Romania registered some of the highest increases in fuel prices for the gasoline, ranking behind Greece, with an increase of $76 \%$ and behind 
Poland, Hungary and Cyprus for diesel prices, with an increase of 62\% over the period 20092012. As the level of gasoline and diesel reduced, Romania still has enough space for the rise of retail oil prices and this could be a sign of potential exchange rate movements.

To investigate this relationship, (Tiwari et al., 2013) use a discrete wavelet transform approach and scale-by-scale Granger causality tests. The authors conclude that an increase of the oil prices is associated with a strong real appreciation of the Romanian 'leu'. Besides this, the oil prices influence the behaviour of the exchange rate not only in the short-run, but also for longer time horizons. In this context, if there are problems of DD in the Romanian economy, its negative effects will be manifested in a continuous way. These results are also particularly important considering the fact that there remains sufficient room for further increases in the level of the retail oil prices in Romania. Consequently, the Romanian monetary authorities could be required to undertake considerable efforts in their attempt to stabilise the exchange rate, and to pay particular attention to shocks in oil prices when defining short and long-run exchange rate targets.

But if shocks in the oil prices can significantly influence the development and economic integration of Central and Eastern European countries, the liberalisation of capital movements can also play an important role in the transition process of these economies, namely by the effects that FDI could have on the behaviour of their RER.

(Carmen, 2010) analyses the impact of FDI on foreign exchange market evolution in Central and Eastern European countries. Evidence proves that accession to the EU comes with important flows of FDI, a situation that creates great benefits for the economies of Central and Eastern European countries. Indeed, large amounts of inward FDI have constituted the engine for quick development in those countries. In this case, at least at an early stage, these capital inflows would not have contributed to any symptoms of DD in their economies. However, the author also concludes that the recent financial crisis showed that the large exposure of Central and Eastern European countries to foreign investors can cause great turmoil once these funds exit the economy, therefore suggesting the possibility of the occurrence of similar effects to those caused by a typical situation of DD due to the negative impact that this turmoil may have on the behaviour of the exchange rate.

This situation could be even more worrying if we take into account the regional dimension of the phenomenon. Indeed, certain regions in Central and Eastern European countries are particularly exposed and vulnerable to its regional dimension and other types of external negative shocks. European funds can play an important role in the correction of these imbalances. However, it is important to analyse the extent to which these funds are absorbed, 
since if they are not used efficiently, they may produce results contrary to expectations and thus further increase the negative effects of the disease.

Starting from a comparative assessment of the efficiency of Eastern European countries in attracting European funds, and their impact on economic growth, (Lupu and Asandului, 2015) analyse exactly the effectiveness of structural funds management by the various regions in Poland, Bulgaria and Romania, determining the main factors that influence efficiency and its practical implications for local development. The authors' estimations confirm the strong need for systemic reforms in the organisation and operation of the development regions. Specifically, the paper shows that the modification of the current transfer system, the strengthening of financial autonomy, and the resolution of the problem of excessive fragmentation of administrative-territorial structure are fundamental requirements for the development of the regions. Otherwise, if not carried out effectively, all these aspects will have a negative impact on the efficiency of absorption of European funds, thereby jeopardising both these countries' own processes of transition, and their European integration.

In this context, everything seems to indicate that for Central and Eastern European countries, the investigations developed in the framework of the so-called Dutch Disease phenomenon are not unanimous about the presence of long-term negative effects in terms of competitiveness and economic growth, although the syndrome has sometimes been analysed in an indirect way, the literature is limited to a very small number of papers.

It is our expectation that the following section of this chapter where we develop our applied study for a group of Central and Eastern European countries could help to clarify this influence.

\section{Symptoms of Dutch Disease: Empirical Analysis Applied to a Group of Countries}

We have selected the following countries of the European enlargement process: Bulgaria, Czech Republic, Estonia, Latvia, Lithuania, Hungary, Poland, Romania, Slovenia, and Slovak Republic. Due to our interest in the effects of European aid funds, we restricted our analysis to the period 2003 to 2013. This funding is grouped under the designation of Structural Funds (SF), and corresponds to different policy actions during those years. We register them by the year in which they were received. At the same time, we retain also the inflow of external current transfers $\left(\mathrm{SF}_{-} \mathrm{T}\right)$ among other items of remittances to these 
countries that we take account of. These variables were taken as percentages of GDP and were obtained by direct contact with European Commission Services and Eurostat.

The other variables retained were: RGDPpc - Real GDP per capita; GDPGR - Real GDP growth rate; TCR - Total current revenue (government) in percentage of GDP; IG Intermediate consumption (government) in percentage of GDP; G - Final consumption (government) in percentage of GDP; CE - Current expenditure (government) in percentage of GDP; KG - Gross fixed capital formation (government) in percentage of GDP; NL - Net lending (government) in percentage of GDP; SRIR - short term interest rate; LRIR - long term interest rate; RER - real exchange rate (base 2010); TG = VAIECB / TVA and NTG = 1TG, with TVA - Total value added and VAIECB - Industry VA excluding Construction and Building. In respect of these two last variables we intend to have proxies for tradable goods and non-tradable goods production, respectively. All these variables are from the AMECO European database.

From 2003 to 2013, Bulgaria was the poorest of these countries in terms of GDP per capita (at 2010 prices), $3600 €$ and $5400 €$, respectively, while the richest country at 2003, the Czech Republic, registered 5400€, and at 2013, Slovenia, registered $17100 €$. The differences between these countries is very considerable.

In terms of evolution we detect two sub-periods (Figure 1), the first one up to 2008, and the second after 2009. After the growth of the first period we have a quasi-stagnation. We confirm the presence of two groups of countries (Figure 2), which have remained more or less constant in their relative differences even if the inequality characterizing the groups is reduced (Figure 1) from 2003 to 2013 with the Gini index decreasing from 0.219 to 0.168 .

\section{[Insert Figures 1 and 2]}

The international financial crisis had a considerable negative impact on growth rates of real GDP (Figure 3) and on investment (Figure 4), but at the same time the sustainable appreciation of the real exchange rate (Figure 5) had finished and began to decrease and so after a period of loss of international competitiveness, we have in recent years, gains in terms of international prices. This clearly was a consequence of the evolution of inflation. After a period of acceleration of prices until 2009, we now have an inflation rate around $2 \%$ (Figure $6)$.

\section{[Insert Figures 3 and 4]}

\section{[Insert Figures 5 and 6]}

The accession process has not brought about the decrease of interest rates (Figures 7 and 8) as this also happened in other countries such as Ireland, Greece, Spain and Portugal. 
The dispersion of values is more important for higher than lower values. In real terms we even register a slight growth, so it is not expected that a growth in demand contributes to the increase of RER by this channel. The same cannot be said of the public budget components on total demand. After 2009 not only did current expenditures increase to a higher degree as the dispersion of the different countries behaviour reduced, but the Gini index moved from 0.083 to 0.075 (Figure 9). The answer given by all these countries was almost the same in terms of this expenditure, with the Gini index registering the minimum value of 0.046, half the value of 2003. The same indication is given by the inter-quantile range.

\section{[Insert Figures 7 and 8] \\ [Insert Figures 9 and 10]}

One of the effects of the presence of DD is on the relative participation of tradable goods in the total value add of an economy. Our proxy (Figure 10) has a slight configuration of a "V" coinciding with the inverse evolution of the real exchange rate (Figure 5). The positive association between structural funds or external inflows with the appreciation of the real exchange rate is clear in the non-parametric representation (Figures 11 and 12). Likewise, the negative relationship between the GDP real growth rate and the real exchange rate.

\section{[Insert Figures 11 and 12]}

So far, from this somewhat descriptive analysis we are able to establish a link between structural funds, or external inflows, and GDP growth by way of the effect on this last variable on the real exchange rate. In the following paragraphs, we analyse the stationarity characteristics of the variables that will be used later in our models.

\subsection{Unit Root Tests of the Relevant Variables}

We apply an ADF test to panel data with the null hypothesis (H0) as the presence of the unit root in all series against the alternative at least one of the series, is stationary. This test is built as a combination based on the inverse of the Normal distribution of the significance levels of the ADF tests (Choi, 2001). For $N$ fixed individuals and $T$ observations sufficiently numerous $(T \rightarrow \infty)$, in the case of $\mathrm{HO}$ :

$$
Z:=\frac{1}{\sqrt{N}} \cdot \sum_{i=1}^{N} \Phi^{-1}\left(p_{i}\right) \stackrel{d}{\rightarrow} N(0,1)
$$


In this formulation the test supposes the independence of the correlation between individuals. (Costantini and Lupi, 2013) propose the correction of the dependence based on (Hartung, 1999; and Demetrescu et al., 2006). From (Demetrescu et al., 2006) we have:

$$
\hat{\mathrm{Z}}_{H}:=\frac{\sum_{i=1}^{N} \Phi^{-1}\left(p_{i}\right)}{\left\{N \cdot\left[1+\left(\hat{\rho}^{*}+0.2 \cdot \sqrt{\frac{2}{N+1}} \cdot\left(1-\hat{\rho}^{*}\right)\right) \cdot(N-1)\right]\right\}^{1 / 2}}
$$

Where $\hat{\rho}^{*}$ is a convergent estimator of $\rho$, the common correlation in $\Phi^{-1}\left(p_{i}\right)$ :

$$
\hat{\rho}=\left(1-(N-1)^{-1} \cdot \sum_{i=1}^{N}\left(\Phi^{-1}\left(p_{i}\right)-N^{-1} \cdot \sum_{i=1}^{N} \Phi^{-1}\left(p_{i}\right)\right)^{2}\right.
$$

We will apply this test without or with trend. We also test the covariate augmented Dickey-Fuller test (CADF) proposed in (Costantini and Lupi, 2013), and based on (Hansen, 1995; and Hanck, 2013). Originally this tests the presence of a unit root in panel data without or with sectional correlation (Pesaran, 2004). In relation to the ordinary ADF test this one benefits from the demonstration by (Hansen, 1995) of a power test gain when we include a stationary variable in the augmented estimation equation. The new equation is now, at the individual level:

$$
a(L) \cdot \Delta Y_{t}=\delta \cdot Y_{t-1}+b(L) \cdot \Delta x_{t-1}+e_{t}
$$

Where $a(L)$ and $b(L)$ are polynomial lags, $\Delta x$ is the added covariate and the errors $\left(e_{t}\right)$ have the normal characteristics. (Costantini and Lupi, 2013) suggest using as a stationary variable, the average of the first difference applied to all individuals or the first difference of the first principal component of the variable. This change allows a superior power test when compared to the usual averages of ADF tests. The correction of cross-section correlation supposes that the significance level of the (Pesaran, 2004) test is less than a typical value. One acceptable choice is 10\%. We use a test based on (Hartung, 1999; and Demetrescu et al., 2006) that will automatically correct the sectional correlation with the threshold of $10 \%$ including as covariate, the first difference of the original variable. We also apply this test with a constant and with a constant and trend. These four tests will be identified by $\mathrm{Zh}, \mathrm{Zh}(\mathrm{t})$, $\mathrm{pCADF}$ and $\mathrm{pCADF}(\mathrm{t})$, respectively, where $(t)$ stands for the presence of a trend. 
The most interesting result is the dubious characteristic of real GDP (Table 1). In levels we can reject the unit root but in first differences we are not able to reject it, even in the first difference of this last one. We cannot reject the unit root in the following variables: NL, CE, SRIR (but not in LRIR) and K. For the other variables, RER, TCR, IG, TG, LRIR, $\mathrm{G}, \mathrm{KG}, \mathrm{SF}$ and SF_T we can reject the presence of a unit root, in most situations through the CADF tests.

\section{[Insert here Table 1]}

These results recommend the use of non-stationary methods in the econometric strategy in the next section.

\subsection{Econometric Models}

We are interested in obtaining models for GDP and RER determination to confirm the hypothesis regarding the presence of DD in these groups of Central and Eastern European countries. We study models in which we have included relevant control variables. The variables retained for GDP growth (equation 5) in addition to the RER are the current revenue of government obtained from the private sector (TCR) that represents a crowding-out resources effect, the level of public final consumption in the economy (G) and also of intermediate consumption (IG), and current expenditures (CE) that represent a crowding-out expenditures effect, as well as the net lending (fiscal balance, NL) that resumes those last variables, and financial costs measured by the short-run interest rate and the long-run interest rate (SRIR and LRIR). For the determination of the real exchange rate (equation 6) we have retained the structural funds $(\mathrm{SF})$, the inflow of external current revenues $\left(\mathrm{SF} \_\mathrm{T}\right)$, the production structural transformation in terms of tradable and non-tradable goods production (TG and NTG), and the level of public investment in the economy (KG).

$$
\begin{aligned}
& G D P G R_{t}=F\left(R E R_{t} ; \mathrm{X}_{t}\right) \\
& \operatorname{RER}_{t}=F\left(S F_{t}, Z_{t}\right)
\end{aligned}
$$

where $X$ and $Y$ represent vectors of control variables.

The fact that some variables that should be included in our equations have a unit root does not allow the application of simple stationary estimation methods. But in our opinion the number of observations is too small for using DOSL (Dynamic Ordinary Least Squares) 
methodology, so we use ADL (Autoregressive Distributed Lag) models. The presence of the lagged dependent variable when the estimation is made by OLS produces inconsistent estimates so we use the General Method of Moments (GMM)-system estimators with the two step methodology (Arellano and Bond, 1991; and Blundell and Bond, 1998). The results of our estimations for equation (5) are in Tables 2 and 3.

\section{[Insert Tables 2 and 3]}

The null of the second lag of the dependent variable is not rejected in equations GMM.1, 4, 5, 6, 8 and 9, but the joint null of the lags of these variables is rejected at levels of 1\%. Of the nine equations, GMM.1-GMM.9 only GMM.2 has a problem with the rejection of no-autocorrelation of order 2 at a level of $10 \%$. Beyond this result, all the estimations are robust by the standard evaluation tests. No problems of second order autocorrelation or overidentification occur, and there is always the single and/or joint rejection of the null for all the parameters of every model. In the retained models, all the variables that represent a possible crowding-out effect of private expenditure or resource allocation have a negative sign, implying a negative effect over the countries' growth rates. The same effect is obtained for the interest rates, short and long-run. The best-fitting model is GMM.8 (Table 3):

$$
G D P G R_{t}=\beta_{0}+\beta_{1} L_{R E R_{t-1}}+\beta_{2} T C R_{t}+\beta_{3} L R I R_{t}+\lambda_{1} G D P G R_{t-1}+\lambda_{2} G D P G R_{t-2}+\varepsilon_{i, t}
$$

The real exchange rate has a negative effect on growth as well as government current revenue and the long-run interest rate.

The results for equation (6) appear in Table 4. All estimations reject the presence of autocorrelation, over-identification and the null of all parameters of the model. The bestfitting model is GMM.12:

$$
R E R_{t}=\alpha_{0}+\alpha_{1} S F_{-} T_{t}+\alpha_{2} S F_{-} T_{t-1}+\alpha_{3} K G_{t}+\gamma_{1} R E R_{t-1}+\mu_{i, t}
$$

\section{[Insert Table 4]}

The real exchange rate is positively influenced by the inflow of external current incomes and by the level of public investment. We confirm that in two models (GMM.1 and 2) the level of structural funds is present with its positive influence over the real exchange rate. 


\section{Conclusion}

It has been shown how the original concept of DD has been enlarged to include not only natural resources, but also financial external inflows and financial costs. The presence or absence of DD in the process of European integration is an issue of importance since it may serve to prevent a no-convergence path due to the loss of competitiveness experienced by countries being helped through European funds transfers. This study has analysed the way in which a group of Central and Eastern European countries managed to use the EU funds made available to them to promote economic growth, competitiveness and convergence. Some empirical studies report that EU funds have a negligible or even negative impact on convergence, while others imply a significant impact on the economy (Lupu and Asandului, 2015). We have also considered other external transfers in order to analyse their effects on the economic performance of these countries.

We find no significant role for financial costs in the determination of the real exchange rate, as we confirm that interest rates have not registered a huge decrease like that registered by other countries (Ireland, Greece, Portugal and Spain) in the European integration process.

We find a positive influence of external capital inflows, and in particular European structural funds, on the determination of the real exchange rate. This positive influence also extends to non-tradable goods and public investments. At the same time, we have confirmed the negative influence of the real exchange rate for output growth rate in these economies.

The policy implications of the study are that these countries must carefully apply European funds in a way that does not bring about higher internal prices, or if possible, control the nominal exchange rate in accordance; and that they must invest more in the higher qualification of human resources, research and development, innovation, entrepreneurship and industrial clusters, in view of the development of the tradable sector. The development of the tradable sector will lead to the diversification of the economy and therefore long-term sustainable growth.

Concerning the results obtained for the output growth in terms of public crowdingout, it is important that these countries should better withstand the negative effects of public spending and the possible unstable accumulation of debt and excessive exposure to the banking system in the weakened economies as is the situation in the countries at the Euro zone 'periphery' - Greece, Portugal, Spain, and Italy. 


\section{Acknowledgments}

The GEMF is financially supported by the Foundation for Science and Technology. The usual disclaimer applies.

\section{References}

Acosta, P., Lartey, E. and F. Mandelman (2009), "Remittances and the Dutch Disease", Journal of International Economics, 79(1), 102-116.

Adams, C. (2006), "Exogenous Inflows and Real Exchange Rates: Theoretical Quirk or Empirical Reality?”, In Isard, P., Lipschitz, L., Mourmouras, A. and B. Yontcheva (eds.), The Macroeconomics Mangement of Foreign Aid: Opportunities and Pitfalls, Washington DC: International Monetary Fund.

Adams, C. and D. Bevan (2003), Aid, Public Expenditure and Dutch Disease, CSAE WPS/2003-02.

Adams, R. and J. Page (2005), "Do International Migration and Remittances Reduce Poverty in Developing Countries?", World Development, 33(10), 1645-1669.

Algieri, B. (2004), The Effects of the Dutch Disease in Russia, ZEF Bonn Center for Development Research W. P., No. 83.

Allen, M. (2005), The Macroeconomics of Managing Increased Aid Inflows: Experiences of Low-Income Countries and Policy Implications, International Monetary Fund.

Amuedo-Dorantes, C. and S. Pozo (2004), "Workers' Remittances and the Real Exchange Rate: A Paradox of Gifts", World Development, 32(8), 1407-1417.

Amuzegar, J. (1982), “Oil Wealth: A Very Mixed Blessing”, Foreign Affairs, 60, 814-835.

Andrade, J. S. and A. P. Duarte (2013), The Dutch Disease in the Portuguese Economy, GEMF Working Paper No. 5, FEUC.

Arellano, M. and S. Bond (1991), "Some Tests of Specification for Panel Data: Monte Carlo Evidence and an Application to Employment Equations", The Review of Economic Studies, 58: 277-297.

Athukorala, P. and S. Rajapatirana (2003), "Capital Inflows and the Real Exchange Rate: A Comparative Study of Asia and Latin America", The World Economy, 26, 613-637. 
Auty, R. (1994), “Industrial Policy Reform in Six Large Newly Industrializing Countries: The Resource Curse Thesis", World Development, 22, 11-26.

Auty, R. (2004), "Natural Resources, Governance and the Transition in Energy-Rich Azerbaijan, Kazakhstan and Turkmenistan. In S. Akiner (ed.), The Caspian: Politics, Energy and Security, Central Asia Research Forum, Routledge Curzon, Abingdon, $109-125$.

Auty, R. and A. Gelb (2000), "Political Economiy of Resource Abundant States", World Bank Annual Conference on Development Economics, 1-13.

Auty, R. and D. Evans (1994), Trade and Industrial Policy ofr Sustainable-based Development: policy issuea, achievements and prospects, UNCTAD, Geneva.

Balassa, B. (1964), “The Purchasing Power Doctrine: A Reappraisal”, Journal of Political Economy, 72, 584-96.

Barder, O. (2006), A Policymakers' Guide to Dutch Disease, Center for Global Development W. P., 91, 1-18.

Barry, F. and J. Bradley (1997), "FDI and Trade: The Irish Host-Country Experience", Economic Journal, 107(445), 1798-1811.

Bayangos, V. and K. Jansen (2011), "Remittances and Competitiveness: The Case of the Philippines”, World Development, 39(10), 1834-1846.

Bayramov, G. and P. Conway (2010), The Azerbaijan Producers Survey: Dutch Disease and Financial Crisis, Azerbaijan Producers Survey, July.

Bayulgen, O. (2005), "Foreign Investment, Oil Curse, and Democratization: A Comparison of Azerbaijan and Russia", Business and Politics, 7(1), 3-3.

Bénassy-Quéré, A., Mignon, V. and A. Penot (2007), "China and the Relationship between the Oil Price and the Dollar", Energy Policy, 35(11), 5795-5805.

Blake, A. and Gooroochurn, J. (2005), Tourism Immiseration: Fact or Fiction, Second International Conference on 'Tourism and Sustainable Economic Development', Crenos-Fondazione Eni Mattei.

Blundell, R. and S. Bond (1998), "Initial Conditions and Moment Restrictions in Dynamic Panel Data Models", Journal of Econometrics, 87: 115-143.

Bourdet, Y. and H. Falck (2006), "Emigrant's Remittances and Dutch Disease in Cape Verde", International Economic Journal, 20(3), 267-284.

Brakman, S. and C. Marrewijk (2005), Transfers, Non-Traded Goods, and Unemployment: An Analysis of the Keynes-Ohlin Debate, CESifo Working Paper Series, 1588. 
Broz, T. and D. Dubravčić (2011), "The Dutch Disease in Unwonted Places - Why has Croatia been Infected While Slovenia Remains in Good Health?”, South-Eastern Europe Journal of Economics, 1, 47-66.

Brunnschweiler, C. and E. Bulte (2008), "The Resource Curse Revisited and Revised: A Tale of Paradoxes and Red Herrings", Journal of Environmental Economics and Management, 55(3), 248-264.

Bruno, M. (1982), Energy and Resource Allocation: a dynamic model of the 'Dutch Disease', National Bureau of Economic Research, Working Paper No. 852.

Bruno, M. and J. Sachs (1982), "Energy and Resource Allocation: A Dynamic Model of the Dutch Disease", Review of Economic Studies, 49(5), 845-859.

Buch, C., Kuckulenz, A. and M.-H. Manchec (2002), Worker Remittances and Capital Flows, Leibniz Information Centre for Economics, Kiel W. P., 1130.

Buiter, W. and D. Purvis (1983), Oil, Disinflation and Export Competitiveness: A Model of the Dutch Disease, National Bureau of Economic Research, Working Paper No. 592.

Burnside, C. and D. Dollar (1977), Aid, Policies and Growth, Policy Research Working Paper, W.B., 1777.

Burnside, C. and D. Dollar (2000), "Aid, Policies, and Growth", The American Economic Review, 90(4), 847-868.

Caimcross (1979), "What is De-industrialisation". In T. Backaby (ed.), De-Industrialisation, London: Heinemann Educational Books.

Carmen, A. (2010), "Central and Eastern European Countries in European Union - Impact of Foreign Direct Investments", Annals of Faculty of Economics, West University, Timisoara, Romania, 1(2), 692-699.

Castro, A. (1970), O que é a Inflação (porque sobem os preços), Lisboa, Edições 70.

Chao, C.-C., Hazari, B., Laffargue, J.-P., Sgro, P. and E. Yu (2006), “Tourism, Dutch Disease and Welfare in an Open Dynamic Economy", The Japanese Economic Review, 57, 501515.

Checherita, C., Nickel, C. and P. Rother (2009), The role of fiscal transfers for regional economic convergence in Europe, Working Paper E. C. B., 1029.

Chen, S. and H. Chen (2007), "Oil Price and Real Exchange Rates”, Energy Economics, 29(3), 390-404.

Choi, I. (2001), "Unit Root Tests for Panel Data", Journal of International Money and Finance, 20(2), 249-72. 
Chrystal, A. 1984. Chrystal, A. (1984), "Dutch Disease or Monetarist Medicine?: The British Economy under Mrs. Thatcher", Federal Reserve Bank of St. Louis Review, 66(5), 2737.

CIEP (2013), Faq 'Dutch Disease', Clingendael International Energy Program (CIEP), CIEP Paper No. 02.

Clements, K., Lan, Y. and J. Roberts (2008), "Exchange-Rate Economics for the Resources Sector", Resources Policy, 33(2), 102-117.

Corden, W (1984), "Booming Sector and Dutch Disease Economics: Survey and Consolidation", Oxford Economic Papers, 36(3), 359-380.

Corden, W. and J. Neary (1982), "Booming Sector and De-Industrialization in a Small Open Economy, The Economic Journal, 92(368), 825-848.

Costantini, M. and C. Lupi (2013), "A Simple Panel-CADF Test for Unit Roots”, Oxford Bulletin of Economics and Statistics, 75(2), 276-96.

Davis, G. (1995), "Learning to Love the Dutch Disease: Evidence from the Mineral Economies", World Development, 23(10), 1765-1779.

Demetrescu, M, Hassler, U. and A.-I. Tarcolea (2006), "Combining Significance of Correlated Statistics with Application to Panel Data", Oxford Bulletin of Economics and Statistics, 68(5), 647-63.

Dorin-Madalin, D. (2015), "The Impact of Structural Funds in Central and Eastern European Countries", Annals of University of Craiova, Economic Sciences Series, 2(43), 293305.

Drelichman, M. (2005), “The Curse of Moctezuma: American Silver and the Dutch Disease", Explorations in Economic History, 42(3), 349-380.

Durbarry, R., Gemmell, N. and D. Greenaway (1998), New Evidence on the Impact of Foreign Aid on Economic Growth, CREDIT Research Paper, 98/8.

Edwards, S. (1985), A Commodity Export Boom and The Real Exchange Rate: The MoneyInflation Link, National Bureau of Economic Research, Working Paper No. 1741.

Égert, B. (2009), Dutch Disease in Former Soviet Union: Witch-hunting?, BOFIT, Discussion Papers No. 4.

Égert, B. (2012), "Dutch Disease in the Post-Soviet Countries of Central and South-West Asia: How Contagious is it?", Journal of Asian Economics, 23(5), 571-584.

Égert, B. and C. Leonard (2008), "The Dutch Disease in Kazakhstan: An empirical Investigation", Open Economies Review, 19(2), 147-165. 
Elbadawi, I. and R. Soto (1997), "Real Exchange Rates and Macroeconomic Adjustment in Sub-Saharan Africa and Other Developing Countries", Journal of African Economies, 6(3), 74-120.

Garber, D. (2004), “Oil, Dutch Disease, and Development: The Case of Chad”, University of Wisconsin Madison W. P.

Gelb, A. and Associates (1990), Oil Windfalls: Blessing or Curse? A Comparative Study of Six Developing Exporters, Oxford University Press, New York.

Godinho, V. M. (1968), "Portugal, as Frotas do Açucar e as Frotas do Ouro (1670-1770). In S. Costa (ed.), Ensaios II, Sobre a História de Portugal, Lisboa: Vitorino Magalhães Godinho.

Gomanee, K. and O. Morrissey (2003), Searching for Aid Threshold Effects, CREDIT Research Paper No. 03/15 03/15.

Gregory, R. (1976), "Some Implications of the Growth of the Mineral Sector", Australian Journal of Agricultural Economics, 20(2), 71-91.

Griffin, K. (1970), "Foreign Capital, Domestic Savings and Economic Development", Bulletin of the Oxford University Institute of Economics and Statistic, 32, 92-112.

Gupta, S., Powell, R. and Y. Yan (2005), The Macroeconomic Challenges of Scaling Up Aid to Africa, IMF W. P., 05/179.

Gylfason, T. (2001a), Lessons from the Dutch Disease Causes, Treatment, and Cures, Institute of Economic Studies, Working Paper Series W01:06.

Gylfason, T. (2001b), "Natural Resources, Education and Economic Development", European Economic Review, 45(4-6), 847-859.

Gylfason, T. and G. Zoega (2006), "Natural Resources and Economic Growth; The Role of Investment", The World Economy, 29(8), 1091-1115.

Hadjimichael, M., Ghura, D., Muhleisen, M., Nord, R. and E. Ucer (1995), Sub-Saharan Africa: Growth, savings, and investment, 1986-93, Occasional Paper IMF, 118.

Hanck, C. (2013), “An Intersection Test for Panel Unit Roots”, Econometric Reviews, 32(2), 183-203.

Hansen, B. (1995), "Rethinking the Univariate Approach to Unit Root Testing: Using Covariates to Increase Power", Econometric Theory, 11(5), 1148-71.

Hansen, H. and F. Tarp (2001), "Aid and growth regressions", Journal of Development Economics, 64(2), 547-570.

Hartung, J. (1999), “A Note on Combining Dependent Tests of Significance”, Biometrical Journal, 41(7), 849-55. 
Hasanov, F. (2013), "Dutch Disease and the Azerbaijan Economy", Communist and PostCommunist Studies, 46(4), 463-480.

Hendry, D and H. Krolzig (2003), "New Developments in Automatic General-to-Specific Modeling. In Princeton (ed.), Econometrics and the Philosophy of Economics: Theorydata Confrontations in Economics, Princeton University Press.

Hendry, D and H. Krolzig (2005), "The Properties of Automatic GETS Modelling", Economic Journal, 115(512), C32-C61.

Hjort, J. (2006), "Citizen Funds and Dutch Disease in Developing Countries", Resources Policy, 31(3), 183-191.

Iimi, A. (2007), "Escaping from the Resource Curse: Evidence from Botswana and the Rest of the World", IMF Staff Papers, 54(4), 663-669.

Javaid, S. (2011), "Dutch Disease Investigated: Empirical Evidence from Selected South-East Asian Economies", Journal of Economic Cooperation and Development, 4(32), 51-74.

Kang, J., Prati, A. and A. Rebucci (2012), "Aid, Exports, and Growth: a Time-Series Perspective on the Dutch Disease Hypothesis", Review of Economics and Institutions, $3(2), 1-26$.

Karapetyan, L. and L. Harutyunyan (2013), The Development and the Side Effects of Remittances in CIS Countries: The Case of Armenia, Research Report, CARIM-East RR 2013/24.

Kenell, L. (2008), Dutch Disease and Tourism: The Case of Tailand, Lund University Department of Economics.

Korhonen, I. and T. Juurikkala (2007), "Equilibrium Exchange Rates in Oil-dependent Countries", BOFIT, Discussion Papers No. 8.

Kronenberg, T. (2004), "The curse of natural resources in the transition economies", The Economics of Transition, 12(3), 399-426.

Krugman, P. (1987), “The Narrow Moving Band, the Dutch Disease, and Competitive Consequences of Mrs. Thatcher", Journal of Development Economics, 27(1-2), 41-55.

Kuralbayeva, K. and D. Vines (2007), "Shocks to Terms of Trade and Risk-premium in an Intertemporal Model: The Dutch Disease and a Dutch Party", Open Economies Review, 19(3), 277-303.

Kutan, A. and M. Wyzan (2005), "Explaining the Real Exchange Rate in Kazakhstan, 19962003: Is Kazakhstan Vulnerable to the Dutch Disease?”, Economic Systems, 29(2), 242255. 
Larsen, E. (1998), Escaping the Natural Resource Curse and the Dutch Disease? Norway's Catching up with and Forging Ahead of Its Neighbors, Unpublished Paper, 1-27.

Larsen, E. (2006), "Escaping the Resource Curse and the Dutch Disease? When and Why Norway Caught Up with and Forged Ahead of its Neighbors", American Journal of Economics and Sociology, 65(3), 605-640.

Lartey, E. (2007), "Capital Inflows and the Real Exchange Rate: An Empirical Study of SubSaharan Africa", The Journal of International Trade and Economic Development, 16(3), 337-357.

Lartey, E. (2008), “Capital Inflows, Dutch Disease Effects and Monetary Policy in a Small Open Economy", Review of International Economics, 16(5), 971-989.

Lartey, E., Mandelman, F. and P. Acosta (2012), "Remittances, Exchange Rate Regimes and the Dutch Disease: A Panel Data Analysis", Review of International Economics, 20(2), 377-395.

Lensink, R. and H. White (1999), Is there an Aid Laffer Curve?, CREDIT Research Paper, $99 / 6$.

Lizardo, R. and A. Mollick (2010), "Oil Price Fluctuations and U.S. dollar Exchange Rates, Energy Economics, 32(2), 399-408.

Loser, C., Lockwood, C., Minson, A. and L. Balcazar (2006), The Macro-Economic Impact of Remittances in Latin America-Dutch Disease or Latin Cure?, Presented at the G-24 Technical Group meeting in Singapore on September 13-14, 1-31.

Lupu, D. and M. Asandului (2015), Comparative Assessment of Efficiency in Attracting European Funds by Regions of Eastern European Countries, CES Working Papers, 7(2A), 531-544.

Mckinley, T. (2005), Why is 'The Dutch Disease' Always a Disease? The macroeconomic Consequences of Scaling Up ODA, International Poverty Centre, U. N, W. P., 10.

Neculita, M. and L. Moga (2014), Comparative Analysis of the European Integration Process in Central and Eastern European Countries, International Conference 'Risk in Contemporary Economy', $\mathrm{XV}^{\text {th }}$ Edition, Galati, Romania.

Neculita, M. and V. Neculita (2014), Analysis of the Structural and Cohesion Funds in Central and Eastern European Countries, International Conference 'Risk in Contemporary Economy', $\mathrm{XV}^{\text {th }}$ Edition, Galati, Romania.

Neculita, M., Sarpe, D., Moga, L. and V. Neculita (2013), "Economic Growth and European Funds Absorption in Central and Eastern European Countries", Acta Universitatis Danubius, 9(4), 177-186. 
Nikas, C. and A. Blouchoutzi (2014), 'Emigrants' Remittances and the 'Dutch Disease' in Small Transition Economies: The Case of Albania and Moldova", Revista Română de Statistică, 1, 45-65.

Nkusu, M. (2004), Aid and the Dutch Disease in Low-Income Countries: Informed Diagnoses for Prudent Prognoses, IMF W. P., WP/04/49.

Oomes, N. and K. Kalcheva (2007), Diagnosing Dutch Disease: Does Russia have the Symptoms?, Bank of Finland, BOFIT Discussion Papers, 7.

Paldam, M. (1997), "Dutch Disease and Rent Seeking: The Greenland Model", European Journal of Political Economy, 13(3), 591-614.

Papyrakis, E. and R. Gerlagh (2004), “The Resource Curse Hypothesis and its Transmission Channels“, Journal of Comparative Economics, 32(1), 181-193.

Pereira, Á. S. (2011), Portugal, Na Hora da Verdade, Lisboa, Gradiva.

Pesaran, M. (2004), "General Diagnostic Tests for Cross Section Dependence in Panels", Cambridge Working Papers in Economics, 0435.

Rajan, R. and A. Subramanian (2005), What Undermines Aid's Impact on Grwoth? IMF Working Papers, 05/126.

Rajan, R. and A. Subramanian (2011), “Aid, Dutch Disease, and Manufacturing Growth”, Journal of Development Economics, 94(1), 106-118.

Rosenberg, C. and O. Saavalainen (1998), How to Deal with Azerbaijan's Oil Boom? Policy Strategy in a Resource-Rich Transition Economy, IMF Working Paper 98/6, Washington, DC.

Rosenberg, C. and T. Saavalainen (1998), How to Deal with Azerbaijan's Oil Boom? Policy Strategies in a Resource-rich Transition Economy, IMF Working Paper 98/6

Ross, M. (1999), “The Political Economy of the Resource Curse”, World Politics, 51(2), 297 322.

Sachs, J. and A. Warner (1995), Natural Resource Abundance and Economic Growth. National Bureau of Economic Research, Working Paper No. 5398.

Sachs, J. and A. Warner (1997), Natural Resource Abundance and Economic Growth, Center for International Development and Harvard Institute for International Development, Harvard University, Cambridge, MA.

Sachs, J. and A. Warner (2001), “The Curse of Natural Resources”, European Economic Review, 45(4-6), 827-838.

Samuelson, P. (1964), "Theoretical Notes on Trade Problems", The Review of Economics and Statistics, 46(2), 145-154. 
Sell, F., Greiner, U. and H. Maab (1999), "The East German Disease Revisited”, IAER, 5, 153-166.

Sheng, L. (2011), "Taxing Tourism and Subsidizing Non-Tourism: A Welfare-Enhancing Solution to 'Dutch disease'?", Tourism Management, 32(5), 1223-1228.

Silva, N., Andrade, J. S. and A. P. Duarte (2016), Alternative Sources of Dutch Disease: A Survey of the Literature, GEMF Working Paper No. 10, FEUC.

Singh, R. and J. Laurila (1999), Azerbaijan: Recent Economic Developments and Policy Issues in Sustainability of Growth, Bank of Finland Institute for Economies in Transition (BOFIT), Discussion Papers, No. 5.

Smirnova, O. and G. Kulkarni (2006), "A Test of Dutch disease Phenomenon in Case of Russia: 1998-2005”, Indian Journal of Economics and Business.

Smith, B. (2015), "The Resource Curse Exorcised: Evidence from a Panel of Countries", Journal of Development Economics, 116, 57-73.

Snape, R. (1977), "Effects of Mineral Development on the Economy", Australian Journal of Agricultural Economics, 21(3), 147-56.

Sosunov, K. and O. Zamulin (2007), Monetary Policy in an Economy Sick with Dutch Disease, Centre for Advanced Studies and New Economic School, Moscow, Working Paper No. 101.

Stijns, J-P. (2005), "Natural Resource Abundance and Economic Growth Revisited", Resources Policy, 30(2), 107-130.

The Economist (1977), “The Dutch Disease”, The Economist, 82.83.

Tiwari, A., Mutascu, M. and C. Albulescu (2013), “The Influence of the International Oil Prices on the Real Effective Exchange Rate in Romania in a Wavelet Transform Framework", Energy Economics, 40, 714-733.

Torvik, R. (2001), "Learning by doing and the Dutch disease", European Economic Review, 45(2), 285-306.

Torvik, R. (2002), "Natural Resources, Rent Seeking and Welfare", Journal of Development Economics, 67(2), 455-470.

Usui, N. (1997), "Dutch Disease and Policy Adjustments to the Oil Boom: A Comparative Study of Indonesia and Mexico", Resources Policy, 23(4), 151-162.

Vos, R. (1998), “Aid Flows and 'Dutch Disease' in a General Equilibrium Framework for Pakistan”, Journal of Policy Modelling, 20(1), 77-109. 
Wijnbergen, S. (1981), Optimal Investment Allocation and Exchange Rate Management in Oil Exporting Countries: A Normative Analysis of the Dutch Disease, Development Research Centre, World Bank.

Wijnbergen, S. (1984), “The 'Dutch Disease': A Disease After All?”, The Economic Journal, 94(373), 41-55.

Wijnbergen, S. (1985), Aid, Export promotion and the Real Exchange Rate: An African Dilemma?, CEPR Discussion Paper, 88.

Ye, Q. (2008), "Commodity Booms and their Impacts on the Western Australian Economy: The Iron Ore Case”, Resources Policy, 33(2), 83-101. 


\section{Figure 1}

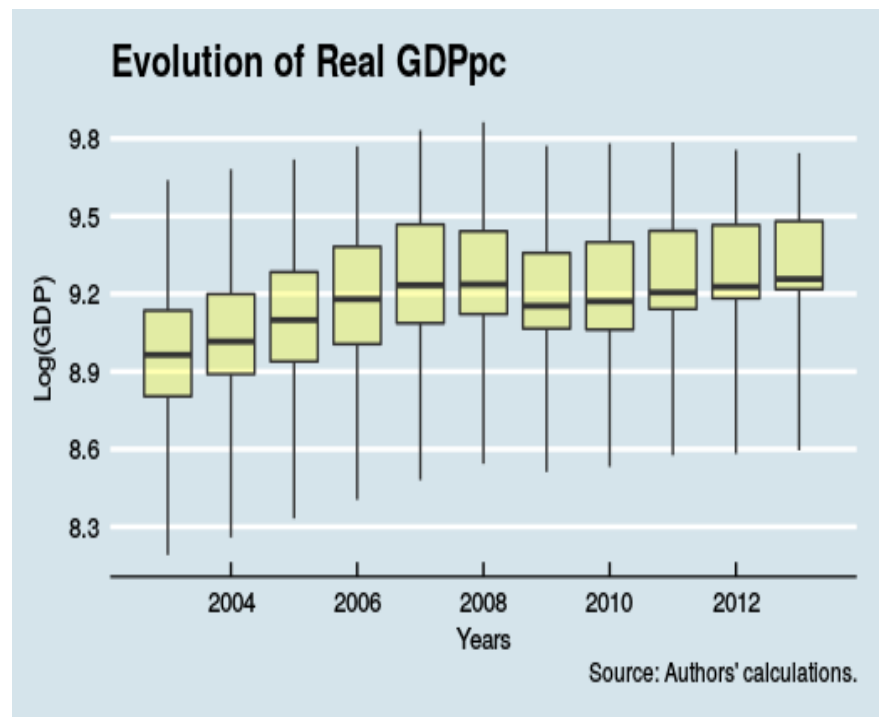

Note: The box of the box-plot figure corresponds to the inter-quantile range the extreme points to the maximum of 3 times this last value.

Figura 2

[theta $=815, \mathrm{phi}=50]$

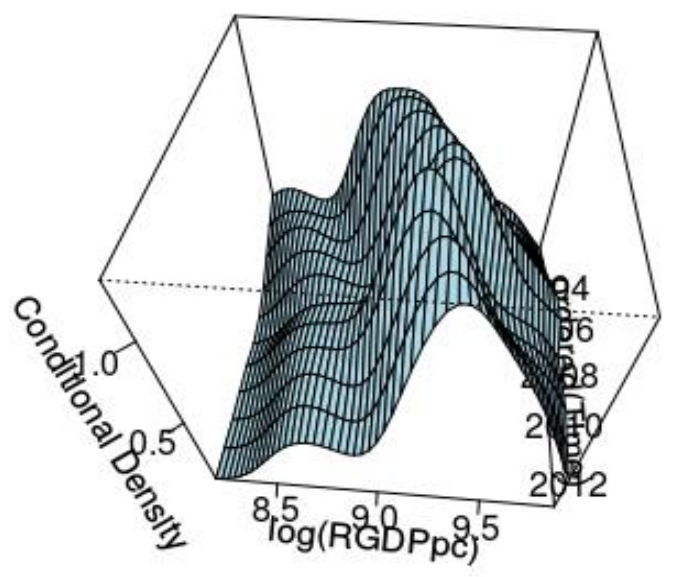


Figure 3

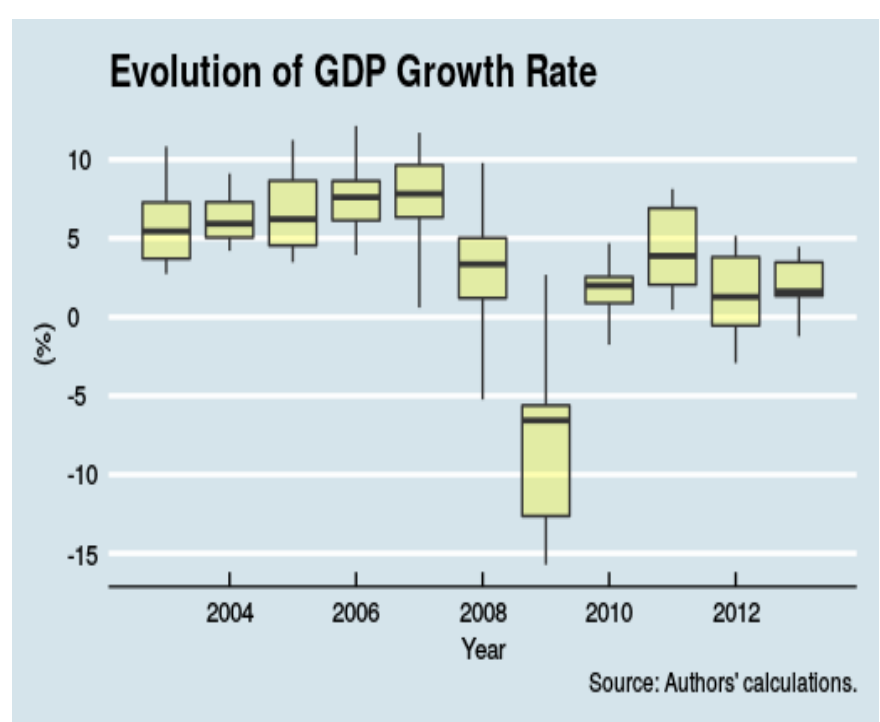

Figure 4

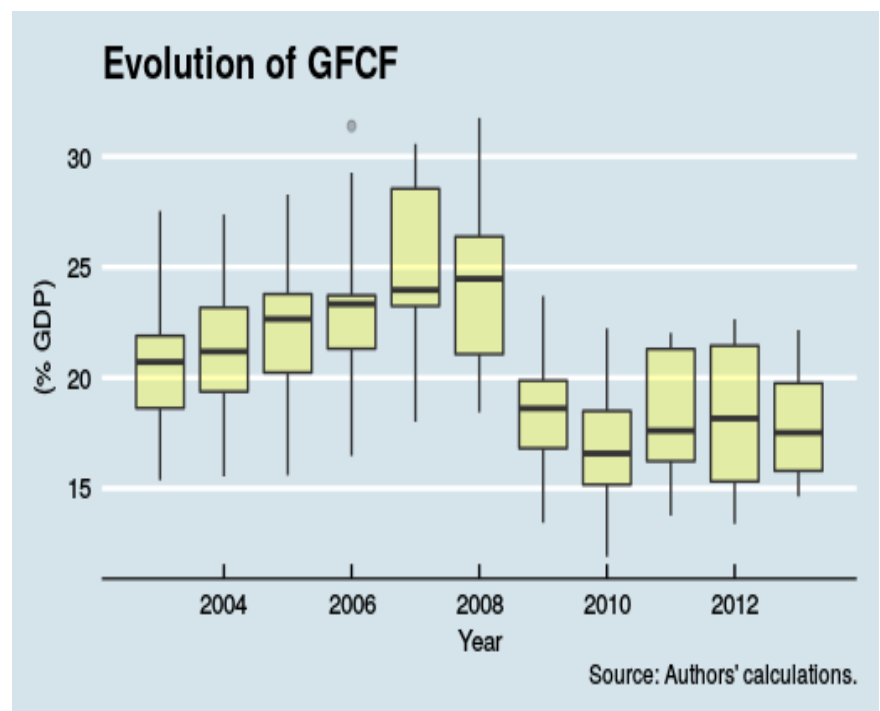




\section{Figure 5}

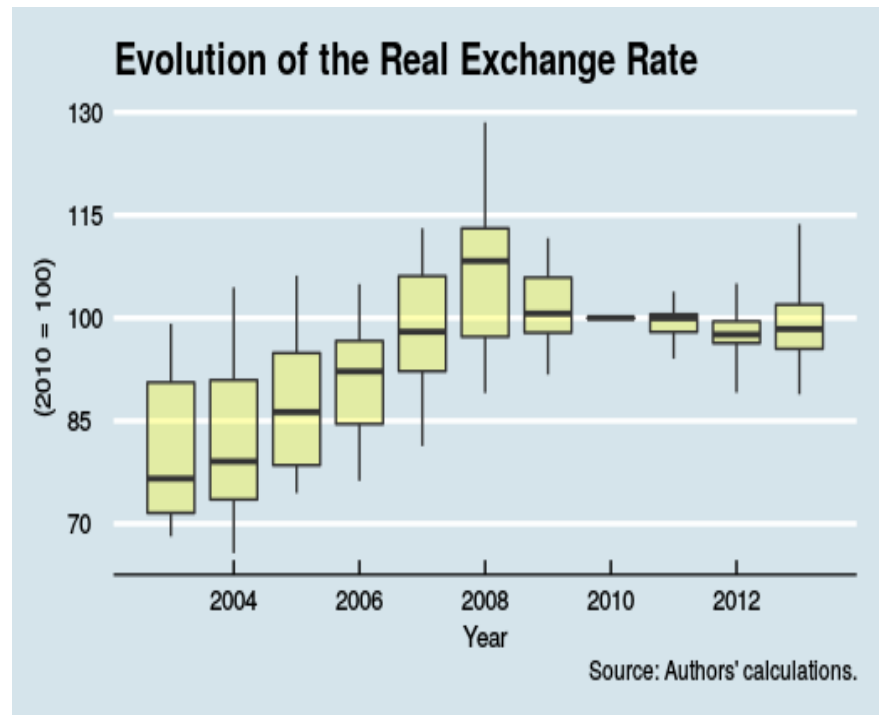

Figure 6

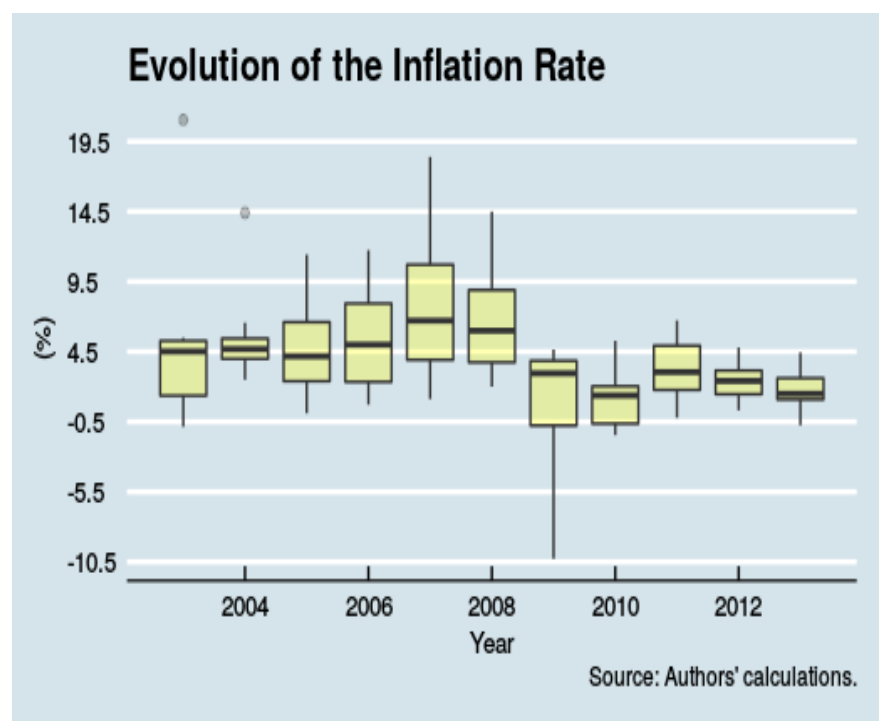


Figure 7

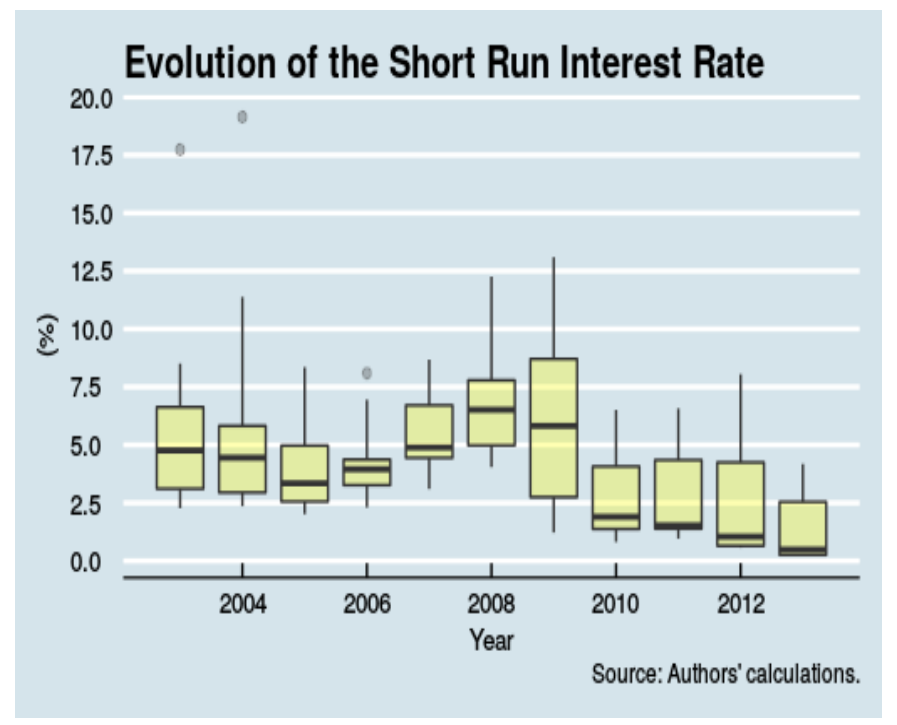

Figure 8

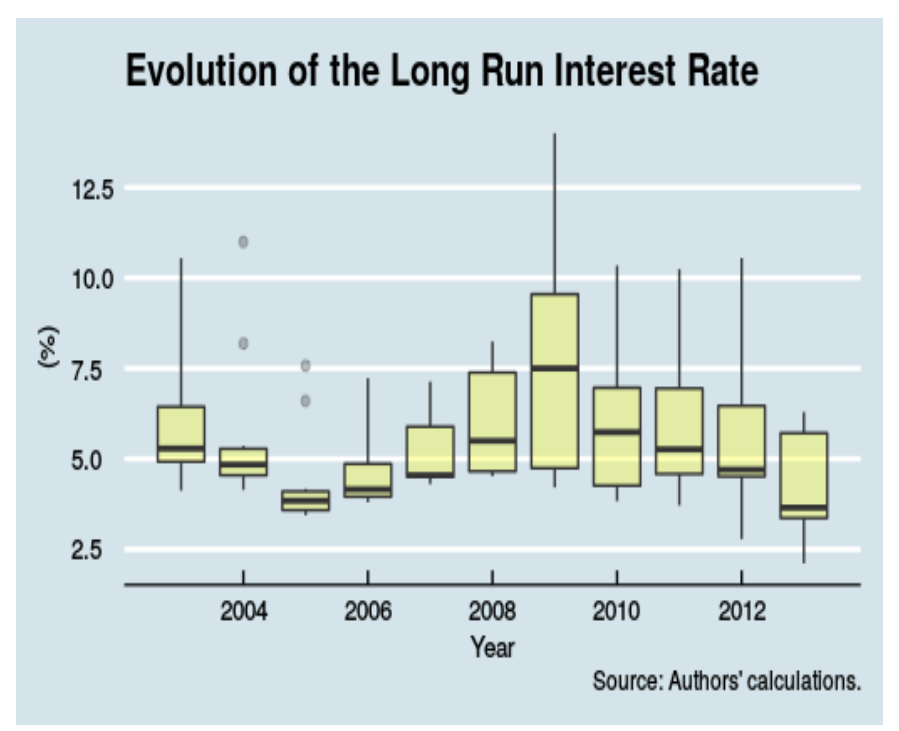


Figure 9

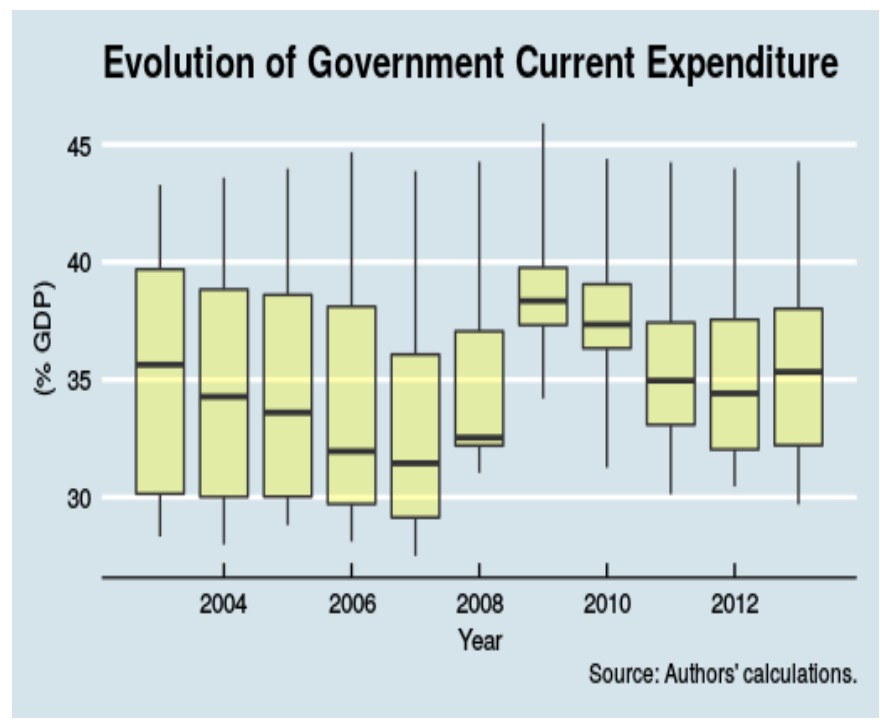

Figure 10

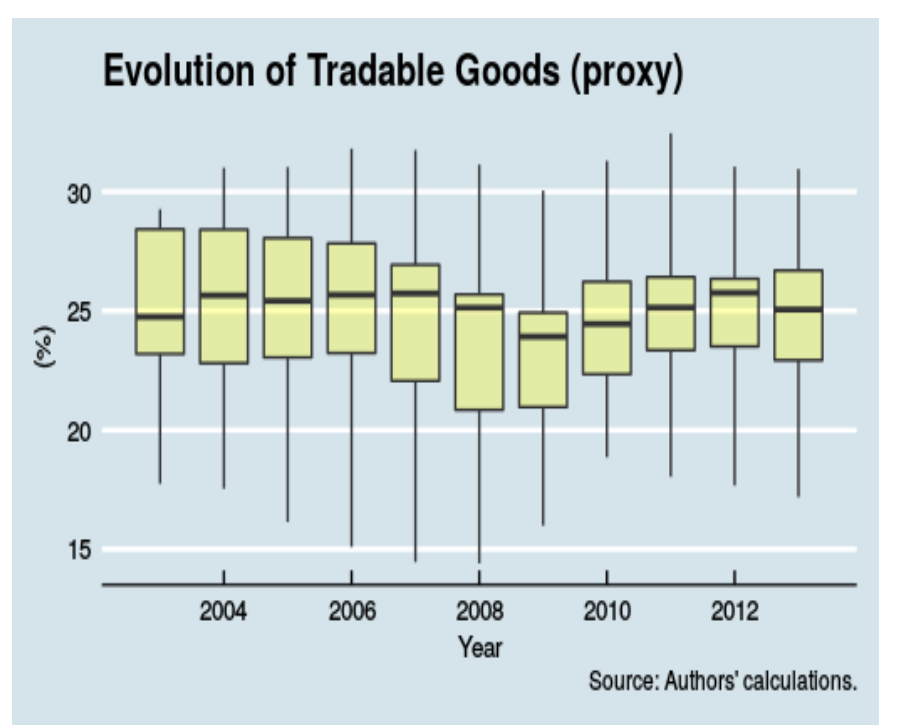




\section{Figure 11}

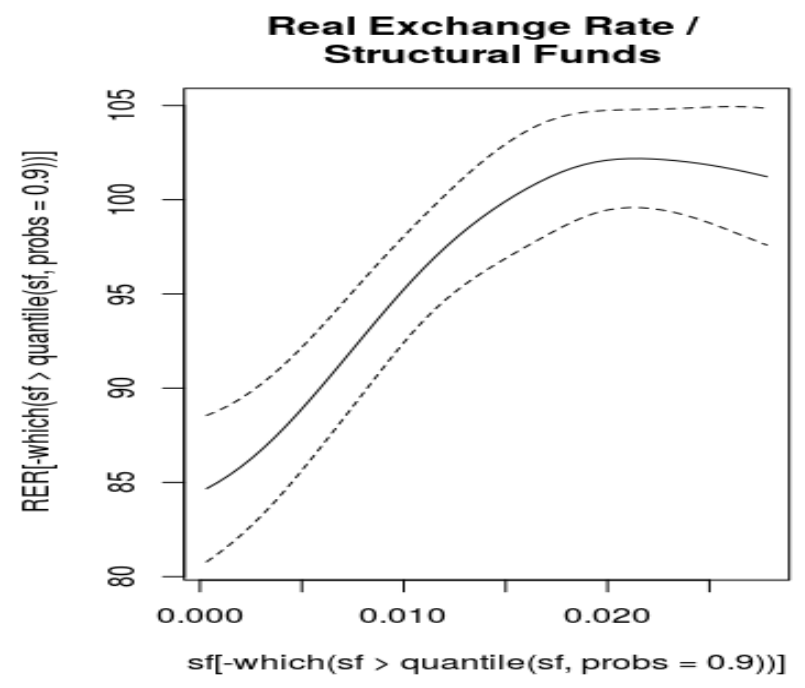

Note: The curve uses a local-constant estimator to the Kernel regression estimator and a lest-squares crossvalidation to select the bandwidth. The $95 \%$ confident intervals were obtained by bootstrap simulation $(\mathrm{n}=1000)$. We have excluded from the scatter outlier values this is values associated with sf greater than the percentile value of $90 \%$.

Figure 12

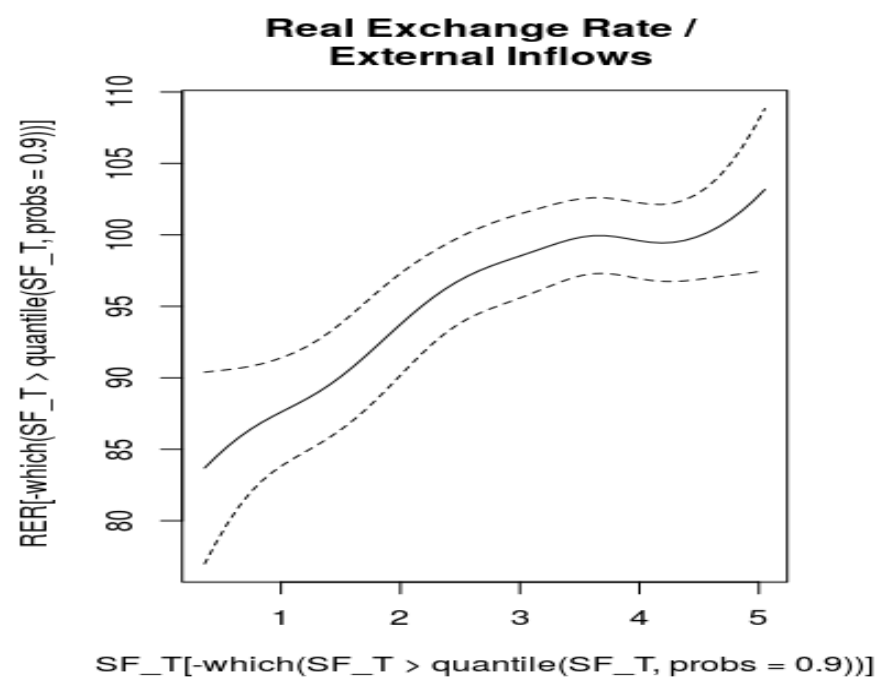

Note: see note on Figure 11. 
Figure 13

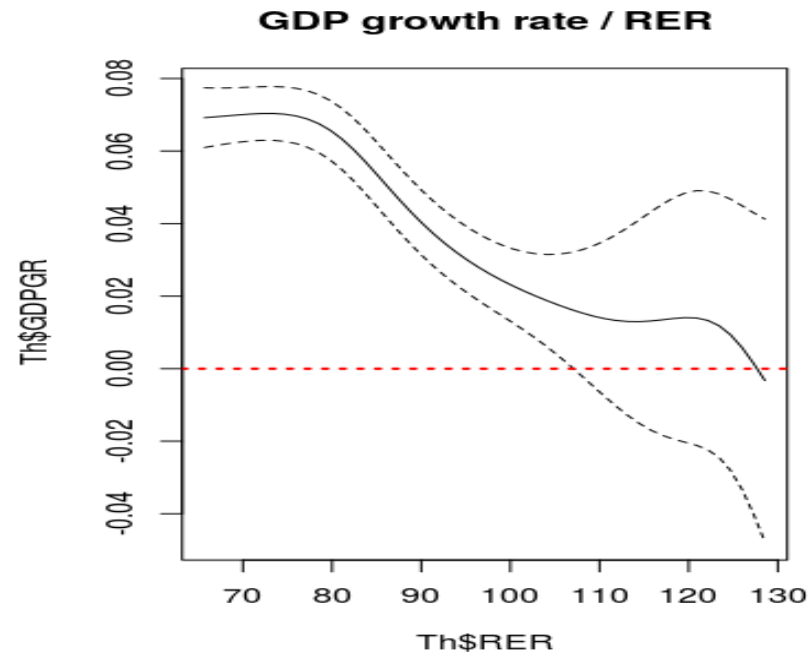

Note: see note on Figure 11. 
Table 1 - Unit Root Tests

\begin{tabular}{|c|c|c|c|c|}
\hline & $\overline{Z h}$ & $\overline{Z h(t)}$ & rCADF & $\begin{array}{l}\operatorname{rCADF}(\mathrm{t}) \\
\end{array}$ \\
\hline LRGDPpc & $-1.296 *$ & 0.131 & $-2.628 * * *$ & $3.218 * * *$ \\
\hline GDPGR & -0.687 & -0.445 & 1.331 & 5.077 \\
\hline d_GDPGR & $-1.638 *$ & -0.928 & 2.26 & 5.858 \\
\hline LRER & $-1.684 * *$ & -0.56 & $-4.147 * * *$ & -0.953 \\
\hline TCR & -0.988 & 0.313 & -0.8 & $-3.012 * * *$ \\
\hline IG & $-1.501 *$ & -1.023 & $-4.064 * * *$ & $-3.001 * * *$ \\
\hline $\mathrm{TG}$ & -0.9 & -0.189 & $-2.118 * *$ & $-3.251 * * *$ \\
\hline NL & -0.694 & -0.306 & -0.371 & 1.16 \\
\hline d_NL & $-1.33 *$ & -0.677 & $-1.323 *$ & -0.096 \\
\hline $\mathrm{CE}$ & -0.519 & -0.371 & -1.119 & -0.648 \\
\hline d_CE & -1.184 & -0.643 & $-1.635 * *$ & -0.622 \\
\hline SRIR & 3.111 & 1.718 & -0.016 & -1.07 \\
\hline d_SRIR & $-3.128 * * *$ & $-1.294 *$ & $-3.24 * * *$ & $-1.968 * *$ \\
\hline LRIR & $-1.287 *$ & -0.346 & $-4.513 * * *$ & $-5.378 * * *$ \\
\hline $\mathrm{K}$ & 0.031 & -0.691 & 1.938 & -0.055 \\
\hline d_K & -1.177 & -0.687 & -0.926 & $8.177 * * *$ \\
\hline G & -1.096 & -0.54 & $-2.928 * * *$ & $-2.04 * *$ \\
\hline TG & -0.919 & -0.11 & $-2.715 * * *$ & $-3.348 * * *$ \\
\hline $\mathrm{KG}$ & -1.084 & 0.955 & $-7.603 * * *$ & $-7.327 * * *$ \\
\hline SF_T & 1.852 & -1.181 & 2.816 & $-2.556 * * *$ \\
\hline SF & 2.069 & $-2.159 * *$ & 1.443 & $-4.135 * * *$ \\
\hline
\end{tabular}

Note: the stars have the usual meaning, *,** and *** for the rejection of the null at $10 \%, 5 \%$ and $1 \%$. A variable with "d_" means first difference. 
Table 2 Models for GDP Growth Rate

\begin{tabular}{|c|c|c|c|c|c|c|c|c|c|c|c|c|c|c|c|}
\hline \multirow[t]{2}{*}{ GDPGR } & \multicolumn{3}{|c|}{ GMM.1 } & \multicolumn{3}{|c|}{ GMM.2 } & \multicolumn{3}{|c|}{ GMM.3 } & \multicolumn{3}{|c|}{ GMM.4 } & \multicolumn{3}{|c|}{ GMM.5 } \\
\hline & Coeff. & $\mathrm{z}$ & $\mathrm{p}-\mathrm{v}$ & Coeff. & $\mathrm{Z}$ & $\mathrm{p}-\mathrm{v}$ & Coeff. & $\mathrm{z}$ & $\mathrm{p}-\mathrm{v}$ & Coeff. & $\mathrm{Z}$ & $\mathrm{p}-\mathrm{v}$ & Coeff. & $\mathrm{z}$ & $\mathrm{p}-\mathrm{v}$ \\
\hline Constant & 1.399 & 5.360 & $* * *$ & 0.9932 & 2.553 & $* *$ & 1.000 & 2.982 & $* * *$ & 1.068 & 2.427 & $* *$ & 1.020 & 4.297 & $* * *$ \\
\hline GDPGR_1 & 0.089 & 1.341 & & 0.285 & 4.949 & $* * *$ & 0.222 & 3.262 & $* * *$ & 0.266 & & & 0.038 & 0.590 & \\
\hline GDPGR_2 & -0.360 & 9.823 & $* * *$ & -0.2515 & 5.858 & $* * *$ & -0.322 & 12.340 & $* * *$ & -0.272 & 5.008 & $* * *$ & -0.320 & 4.754 & $* * *$ \\
\hline LRER & 0.033 & 0.342 & & -0.195 & 4.463 & $* *$ & -0.170 & 2.315 & $* *$ & -0.203 & 2.198 & $* *$ & & & \\
\hline LRER_1 & -0.332 & 4.278 & $* * *$ & & & & & & & & & & -0.188 & 3.264 & $* * *$ \\
\hline TCR & & & & -0.0082 & 2.931 & $* * *$ & & & & & & & -0.003 & 2.981 & $* * *$ \\
\hline TCR_1 & & & & 0.0062 & 2.230 & $* *$ & & & & & & & & & \\
\hline G & & & & & & & -0.010 & 3.433 & $* * *$ & & & & & & \\
\hline IG & & & & & & & & & & -0.018 & 3.701 & $* * *$ & & & \\
\hline NL & & & & & & & & & & & & & 0.006 & 2.477 & $* *$ \\
\hline $\mathrm{CE}$ & & & & & & & & & & & & & & & \\
\hline SRIR_1 & & & & & & & & & & & & & & & \\
\hline LRIR & & & & & & & & & & & & & & & \\
\hline Sigma & 0.046 & & & 0.045 & & & 0.048 & & & 0.046 & & & 0.042 & & \\
\hline $\operatorname{AR}(2)$ & 0.569 & & & $-1.714 *$ & & & -0.334 & & & 1.408 & & & -0.193 & & \\
\hline Sargan & 8.086 & & & 7.670 & & & 6.884 & & & 7.727 & & & 7.757 & & \\
\hline Wald & 329.437 & & & 129.678 & & & 485.444 & & & 81.935 & & & 109.579 & & \\
\hline
\end{tabular}

Note: For the stars see Note on Figure 1. Sigma is the standard error of the estimate, AR(2) the residuals autocorrelation test of order 2, Sargan is the overidentification test for instruments and Wald a test of joint significance of the regressors. The estimation is a 2-step system estimation. 
Table 3 Models for GDP Growth Rate (Continuation)

\begin{tabular}{|c|c|c|c|c|c|c|c|c|c|c|c|c|}
\hline \multirow[t]{2}{*}{ GDPGR } & \multicolumn{3}{|c|}{ GMM.6 } & \multicolumn{3}{|c|}{ GMM.7 } & \multicolumn{3}{|c|}{ GMM.8 } & \multicolumn{3}{|c|}{ GMM.9 } \\
\hline & Coeff. & $\mathrm{z}$ & $\mathrm{p}-\mathrm{v}$ & Coeff. & $\mathrm{z}$ & $\mathrm{p}-\mathrm{v}$ & Coeff. & $\mathrm{z}$ & $\mathrm{p}-\mathrm{v}$ & Coeff. & $\mathrm{z}$ & $\mathrm{p}-\mathrm{v}$ \\
\hline Constant & 0,955 & 2,887 & $* * *$ & 1,142 & 3,455 & $* * *$ & 1,237 & 4,572 & $* * *$ & 0,771 & 3,017 & $* * *$ \\
\hline GDPGR_1 & 0,129 & 0,210 & & 0,251 & 2,928 & $* * *$ & 0,098 & 0,885 & & $-0,049$ & 0,417 & \\
\hline GDPGR_2 & $-0,289$ & 5,215 & $* * *$ & $-0,222$ & 3,459 & $* * *$ & $-0,280$ & 4,918 & $* * *$ & $-0,364$ & 5,019 & $* * *$ \\
\hline LRER & $-0,155$ & 2,193 & $* *$ & $-0,218$ & 3,144 & $* * *$ & & & & & & \\
\hline LRER_1 & & & & & & & $-0,227$ & 3,763 & $* * *$ & $-0,117$ & 1,914 & $*$ \\
\hline TCR & & & & $-0,003$ & 3,670 & $* * *$ & $-0,003$ & 2,511 & $* *$ & $-0,003$ & 2,678 & $* * *$ \\
\hline NL & & & & & & & & & & 0,006 & 3,444 & $* * *$ \\
\hline $\mathrm{CE}$ & $-0,006$ & 3,182 & $* * *$ & & & & & & & & & \\
\hline SRIR_1 & & & & $-0,003$ & 2,920 & $* * *$ & & & & & & \\
\hline LRIR & & & & & & & $-0,009$ & 3,167 & $* * *$ & $-0,009$ & 3,126 & $* * *$ \\
\hline Sigma & 0,043 & & & 0,045 & & & 0,041 & & & 0,043 & & \\
\hline $\mathrm{AR}(2)$ & $-0,574$ & & & $-1,337$ & & & $-0,370$ & & & 0,393 & & \\
\hline Sargan & 8,555 & & & 8,065 & & & 9,153 & & & 6,951 & & \\
\hline Wald & 131,534 & & & 116,119 & & & 477,038 & & & 432,819 & & \\
\hline
\end{tabular}

Table 4 Models for the Real Exchange Rate

\begin{tabular}{|c|c|c|c|c|c|c|c|c|c|c|c|c|}
\hline \multirow[t]{2}{*}{ RER } & \multicolumn{3}{|c|}{ GMM.10 } & \multicolumn{3}{|c|}{ GMM.11 } & \multicolumn{3}{|c|}{ GMM.12 } & \multicolumn{3}{|c|}{ GMM.13 } \\
\hline & Coeff. & $\mathrm{Z}$ & $\mathrm{p}-\mathrm{v}$ & Coeff. & $\mathrm{z}$ & $\mathrm{p}-\mathrm{v}$ & Coeff. & $\mathrm{z}$ & $p-v$ & Coeff. & $\mathrm{Z}$ & $\mathrm{p}-\mathrm{v}$ \\
\hline Constant & -70.656 & 1.554 & & 88.463 & 3.960 & $* * *$ & 18.197 & 3.300 & $* * *$ & -105.101 & 1.634 & \\
\hline RER_1 & 0.552 & 7.362 & $* * *$ & 0.393 & 2.990 & $* * *$ & 0.736 & 9.115 & $* * *$ & 0.558 & 4.514 & $* * *$ \\
\hline SF & 0.087 & 1.709 & $*$ & 0.091 & 2.077 & $* *$ & & & & & & \\
\hline NTG & 1.426 & 2.334 & $* *$ & & & & & & & 1.780 & 1.959 & $*$ \\
\hline TG & & & & -1.790 & 2.591 & $* * *$ & & & & & & \\
\hline KG & & & & & & & 1.895 & 2.237 & $* *$ & 2.503 & 2.806 & $* * *$ \\
\hline KG_1 & & & & 1.869 & 1.876 & $*$ & & & & & & \\
\hline SF_T & & & & & & & -2.497 & 4.066 & $* * *$ & -2.150 & 3.335 & $* * *$ \\
\hline SF_T_1 & & & & & & & 2.780 & 3.763 & $* * *$ & 3.091 & 4.051 & $* * *$ \\
\hline Sigma & 10.111 & & & 10.795 & & & 5.870 & & & 9.327 & & \\
\hline $\mathrm{AR}(2)$ & 0.481 & & & 0.846 & & & -0.150 & & & -0.366 & & \\
\hline Sargan & 6.971 & & & 5.346 & & & 6.556 & & & 4.006 & & \\
\hline Wald & 179.149 & & & 153.206 & & & 398.788 & & & 332.004 & & \\
\hline
\end{tabular}




\section{CeBER Working PAPERS}

(Available on-line at www.uc.pt/go/ceber)

2017-03 Dutch Disease in Central and Eastern European Countries - João Sousa Andrade \& António Portugal Duarte

2017-02

On the gains of using high frequency data and higher moments in Portfolio Selection-

2017-01 Rui Pedro Brito, Hélder Sebastião \& Pedro Godinho

Growth adjustments through non-price competitiveness and productivity. A cumulative causation approach-Elias Soukiazis, Micaela Antunes \& Pedro André Cerqueira

A série CeBER Working Papers foi iniciada em 2017. 